Piotr KOCHANEK

(Lublin, KUL)

\title{
UDZIAL POLAKÓW \\ W 21 MIĘDZYNARODOWYCH KONGRESACH BIZANTYNISTÓW W LATACH 1924-2006
}

W aktach XXII Międzynarodowego Kongresu Bizantynistów ${ }^{1}$, który odbył się w Sofii w dniach 22-27 sierpnia 2011 r., zamieszczono dwa artykuły, które zostały również wygłoszone $\mathrm{w}$ formie referatów podczas sesji inauguracyjnej tegoż kongresu w auli Uniwesytetu Sofijskiego im. św. Klemensa Ochrydzkiego w poniedziałek 22 sierpnia przed południem. Chodzi konkretnie o wystąpienia Marii Nystazopoulou-Pélékidou ${ }^{2}$ i Vassilki Tăpkovej-Zaimovej³ ${ }^{3}$ Oba opracowania są poświęcone historii kongresów bizantynologicznych. Do nich należy jeszcze dodać wcześniejszy artykuł M. Nystazopoulou-Pélékidou, opublikowany w 2008 roku$^{4}$. W przypisach tych publikacji można znaleźć bogatą literaturę przedmiotu.

Niniejszy artykuł jest pomyślany jako swoiste uzupełnienie tych prac. Jego tematem jest wyłącznie udział polskich badaczy w kongresach bizantynistycznych. W tej materii bowiem publikacje obu wyżej wymienionych badaczek zawierają pewne nieścisłości, które są konsekwencją każdego ujęcia syntetycznego.

\section{MIĘDZYNARODOWE KONGRESY BIZANTYNISTÓW W STATYSTYKACH}

Owo statystyczne ujęcie kongresów opiera się na dwóch tabelach sporządzonych przez cytowaną już wyżej grecką bizantynistkę prof. M. Nystazopo-

\footnotetext{
${ }^{1}$ Por. P. Kochanek, XXII Międzynarodowy Kongres Bizantynistów (Sofia, 22-27 VIII 2011), VoxP 31 (2011) t. 56, 942-951.

${ }^{2}$ Por. M. Nystazopoulou-Pélékidou, Les congrès internationaux des études byzantines face à la conjoncture historique, w: Proceedings of the 22nd International Congress of Byzantine Studies (Sofia, 22-27 August 2011), vol. 1: Plenary papers, ed. I. Iliev, Sofia 2011, 17-35.

${ }^{3}$ Por. V. Tăpkova-Zaimova, Entre deux congrès, w: tamże, vol. 1, s. 37-66.

${ }^{4}$ Por. M. Nystazopoulou-Pélékidou, L'Histoire des Congrès Internationaux des Études Byzantines - Première Partie, „Byzantina Symmeikta” 18 (2008) 11-33 (tekst tego artykułu jest dostępny również w internecie: www.byzsym.org/index.php/bz/article/view/528/832 [sprawdzono: 26.06.2012]).
} 
ulou-Pélékidou, które to cyfry pretendują dziś do bycia miarodajną syntezą statystyczną wszystkich dotychczasowych kongresów bizantynistów. Jednak, jak już wyżej wspomniano, dane zawarte w tych wykazach, a odnoszące się do polskich uczestników kongresów, zawierają pewne nieścisłości.

Na szczególną uwagę zasługuje tabela nr 1, która ma za zadanie dokładne podanie liczby uczestników pięciu kongresów bizantynistycznych, jakie miały miejsce w okresie międzywojennym. Polska sekcję tej tabeli ma uzupełnić drugi paragraf niniejszego artykułu, opatrzony tytułem Polacy na kongresach bizantynistycznych $w$ okresie międzywojennym. Tutaj została przedstawiona jedynie spolszczona wersja tej statystyki, z której jasno wynika, że pięć przedwojennych kongresów to okres zdecydowanej statystycznej hegemonii Bułgarii, Francji, Grecji, Jugosławii, Rumunii i Włoch; sprzyjała temu już sama lokalizacja tych zjazdów na Bałkanach. Drugim czynnikiem był oczywiście poziom studiów bizantynistycznych w poszczególnych krajach. Nie należy również zapominać o tym, że z wyjątkiem Francji, dla wszystkich pozostałych w/w krajów dzieje Bizancjum są integralną częścią ich własnej historii.

Tabela I: Liczba uczestników pięciu pierwszych kongresów (1924-1936)5

\begin{tabular}{|c|c|c|c|c|c|}
\hline Kraj & $\begin{array}{c}1924 \\
\text { Bukareszt }\end{array}$ & $\begin{array}{c}1927 \\
\text { Belgrad }\end{array}$ & $\begin{array}{c}1930 \\
\text { Ateny }\end{array}$ & $\begin{array}{c}1934 \\
\text { Sofia }\end{array}$ & $\begin{array}{c}1936 \\
\text { Rzym }\end{array}$ \\
\hline Austria & - & 15 & 16 & 1 & - \\
\hline Belgia & 2 & - & 4 & 5 & 14 \\
\hline Bułgaria & 1 & 13 & 10 & 53 & 17 \\
\hline Czechosłowacja & 3 & 22 & 11 & 10 & 14 \\
\hline Cypr & - & - & 1 & - & - \\
\hline Dania & - & 2 & 3 & 1 & 3 \\
\hline Egipt & - & - & 2 & - & - \\
\hline Francja & 12 & 18 & 37 & 10 & 37 \\
\hline Grecja & 2 & 13 & 88 & 14 & 31 \\
\hline Hiszpania & 2 & 2 & 3 & - & 1 \\
\hline
\end{tabular}

${ }^{5}$ Tabela podaję za: Nystazopoulou-Pélékidou, L'Histoire des Congrès, s. 32. Zmieniono tylko kolejność alfabetyczną państw z francuskiej na polską i dodano wiersz podsumowujący poszczególne kolumny tabeli. Pod tabelą w wersji oryginalnej znajduje się pięć przypisów. Pierwszy z nich mówi o tym, że na kongresie w Rzymie dwóch francuskich uczonych nie reprezentowało Francji: Marius Canard (1888-1982) występował jako przedstawiciel Algierii, a Gabriel Millet (1867-1952) reprezentował Tunezję; kraje te nie są jednak ujęte w tabeli. Drugi i trzeci przypis odnosi się do skromniej ekipy tureckiej w Sofii i w Rzymie: Turcy bowiem w każdym z tych spotkań brali udział nieoficjalnie, a w Sofii ich przedstawiciel miał status obserwatora. Natomiast nota czwarta i piąta mówi o ZSRR: przyczyny polityczne są tam podawane jako powód bardzo skromnego udziału Rosjan w kongresach przedwojennych; ponadto odnotowuje się obecność w Rzymie jednego nieoficjalnego przedstawiciela ZSRR o nazwisku V. Valdenberg, pochodzącego z Leningradu, por. też Nystazopoulou-Pélékidou, L'Histoire des Congrès, s. 23.25 oraz s. 25, przyp. 54 i 56. 


\begin{tabular}{|c|c|c|c|c|c|}
\hline Holandia & - & - & 1 & 1 & 2 \\
\hline Irlandia & - & - & - & - & 1 \\
\hline Jugosławia & 8 & 56 & 37 & 35 & 38 \\
\hline Kanada & - & - & - & - & 1 \\
\hline Liban & - & - & - & - & 1 \\
\hline Niemcy & - & 9 & 22 & 12 & 28 \\
\hline Norwegia & - & - & 1 & - & 1 \\
\hline Palestyna & - & - & - & - & 1 \\
\hline Polska & $-*$ & $2 *$ & 3 & $5 *$ & 8 \\
\hline Rumunia & 24 & 26 & 31 & 23 & 51 \\
\hline Syria & - & - & 1 & - & - \\
\hline Szwajcaria & 1 & - & 2 & - & 3 \\
\hline Turcja & - & - & - & 1 & 2 \\
\hline USA & 1 & - & 3 & 3 & 2 \\
\hline Watykan & - & 2 & - & - & - \\
\hline Wegry & - & 3 & 8 & 3 & 9 \\
\hline Wielka Brytania & 2 & 3 & 2 & 2 & 14 \\
\hline Włochy & 2 & 11 & 10 & 13 & 167 \\
\hline ZSRR & - & 2 & - & - & 1 \\
\hline Patriarchat & - & - & 1 & - & - \\
\hline Aleksandrii & & & & & - \\
\hline $\begin{array}{c}\text { Patriarchat } \\
\text { Jerozolimy }\end{array}$ & - & - & 1 & - & 447 \\
\hline Patriarchat & - & - & 1 & - & - \\
Konstantynopola & & - & 299 & 192 & \\
\hline SUMA & 60 & 199 & & & \\
\hline
\end{tabular}

* oznacza rozbieżności pomiędzy danymi M. Nystazopoulou-Pélékidou a stanem faktycznym

Tabela II ma charakter o wiele bardziej ogólny: zestawienie to nie stanowi zatem punktu wyjścia do jakichkolwiek korekt statystycznych, związanych z udziałem Polaków w światowych spotkaniach bizantynistów po II wojnie światowej. Może jednak być traktowane jako swoiste szerokie tło dla szczegółowej, polskiej statystyki; ma też zwrócić uwagę na fakt, że ogólna liczba uczestników poszczególnych kongresów nie jest pewna. W tej materii bowiem zachodzą znaczne rozbieżności, o czym będzie mowa niżej (por. przyp. 14, 37-39, 58). Rozbieżności te ukazują pewne problemy, związane ze sposobami liczenia uczestników poszczególnych kongresów. Nie wszyscy bowiem zgłoszeni de iure ,kongresmeni”, przybywali de facto na dane spotkanie. Nie wszyscy również musieli brać czynny udział w kongresie. Wielu z nich było tylko jego obserwatorami. Ponadto kongresy odbyte w okresie międzywojennym, dzieliły uczestników na oficjalnych przedstawicieli danych państw oraz na resztę, co zdaje się wynikać z akt kongresowych (por. przyp. 9. 15. 20. 46). 
Tabela II: Zestawienie wszystkich dotąd odbytych kongresów bizantynistów ${ }^{6}$

\begin{tabular}{|c|c|c|c|c|}
\hline Kongres & Miejsce & Data & Liczba krajów & Liczba osób \\
\hline I & Bukareszt & 14-20 IV 1924 & 12 & 60 \\
II & Belgrad & 11-16 IV 1927 & 16 & 200 \\
III & Ateny & 12-18 X 1930 & 25 & 300 \\
IV & Sofia & 9-15 IX 1934 & 17 & 192 \\
V & Rzym & 20-26 IX 1936 & 24 & 450 \\
VI & Paryż & 27 VII-2 VIII 1948 & 20 & 330 \\
VII & Bruksela & 4-15 VIII 1948 & 20 & 330 \\
VIII & Palermo & 3-10 IV 1951 & 22 & 320 \\
IX & Saloniki* & 12-19 IV 1953 & 23 & 414 \\
X & Stambuł & 15-21 IX 1955 & 19 & 105 \\
XI & Monachium & 15-20 IX 1958 & 26 & 353 \\
XII & Ochryda & 10-16 IX 1961 & 26 & 400 \\
XIII & Oksford & 5-10 IX 1966 & ok. 30 & brak danych \\
XIV & Bukareszt & 6-12 IX 1971 & 32 & 564 \\
XV & Ateny & 5-11 IX 1976 & 31 & 874 \\
XVI & Wiedeń & 4-9 X 1981 & 35 & 751 \\
XVII & Waszyngton & 3-8 VIII 1986 & 30 & 413 \\
XVIII & Moskwa & 8-15 VIII 1991 & 36 & 1300 \\
XIX & Kopenhaga & 18-24 VIII 1996 & 34 & 430 \\
XX & Paryż & 19-25 VIII 2001 & 33 & 995 \\
XXI & Londyn & 21-26 VIII 2006 & 40 & 948 \\
XXII & Sofia & 22-27 VIII 2011 & 46 & 1106 \\
\hline
\end{tabular}

\section{POLACY NA KONGRESACH BIZANTYNISTYCZNYCH W OKRESIE MIĘDZYWOJENNYM}

W okresie międzywojennym, jak to pokazuje powyższa tabela nr 1, odbyło się pięć kongresów bizantynistycznych. Odrodzona Polska była tam dość skromnie reprezentowana, choć z drugiej strony ilość polskich uczestników kongresów z tamtych lat jest porównywalna z okresem PRL-u.

${ }^{6}$ Poniższa tabela jest nieznacznie tylko zmodyfikowaną wersją (dodano daty dzienne poszczególnych kongresów oraz dane dotyczące ostatniego kongresu w Sofii) tabeli, która znajduje się w: Nystazopoulou-Pélékidou, Les congrès internationaux des études byzantines, s. 32. Natomiast dokładne daty trwania poszczególnych kongresów (z wyjątkiem spotkań międzywojennych) pochodzą grosso modo z: Tăpkova-Zaimova, Entre deux congrès, s. 37-66. W przypisach cytowanych tu artykułów znajduje się bogata literatura przedmiotu.

* Kongres w Salonikach odbył się w wigilię 500-nej rocznicy zdobycia Konstantynopola (29 V 1453), por. Nystazopoulou-Pélékidou, Les congrès internationaux des études byzantines, s. 26. 
$*$

Według prof. M. Nystazopoulou-Pélékidou, Polacy nie brali udziału w I kongresie w Bukareszcie (14-20 IV 1924). Konstatację tę potwierdzają akta kongresowe ${ }^{7}$. W sprzeczności z tymi danymi stoi biografia naukowa prof. dr hab. Jana Sajdaka (1882-1967) z Uniwersytetu Poznańskiego, który miał brać udział m.in. w kongresie bukaresztańskim ${ }^{8}$, choć być może nie występował tam jako oficjalny delegat z Polski, co by tłumaczyło brak jego nazwiska w dokumentach kongresowych i usprawiedliwiało opinię prof. M. Nystazopoulou-Pélékidou, dla której owe akta kongresowe stanowiły podstawowe, a w zasadzie jedyne, źródło informacji. Rozstrzygnięcie tej kwestii utrudnia również to, że w polskiej bibliografii przedmiotu nie ma żadnego sprawozdania $\mathrm{z}$ tego wydarzenia.

W II Międzynarodowym Kongresie Bizantynistów w Belgradzie (11-16 IV 1927) brało, zdaniem cytowanej tu greckiej badaczki, udział 2 Polaków. Problem uczestnictwa Polaków w kongresie belgradzkim jest jednak nieco bardziej skomplikowany. Akta kongresowe bowiem zawierają aż 9 nazwisk obywateli polskich. W kolejności alfabetycznej są to: 1) prof. dr hab. Wojsława Molè (1886-1973) - UJ, 2) prof. dr hab. Ludwik Piotrowicz (1886-1957) - UJ, 3) T. Popiel - Towarzystwo Naukowe im. Tarasa Szewczenki (Lwów), 4) prof. dr hab. Jan Sajdak - Uniwersytet Poznański, 5) prof. dr hab. Leon Sternbach (1864-1940) - UJ, 6) dr Cyryl Studziński (1864-1941) - UJK we Lwowie, 7) dr Hilarion Święcicki (1876-1956) - Towarzystwo Naukowe im. T. Szewczenki (Lwów), 8) M. Terecki - Towarzystwo Naukowe im. T. Szewczenki (Lwów), 9) prof. dr hab. Kazimierz Zakrzewski (1900-1941) ${ }^{9}$ - UJK we Lwowie. Jednak obok kilku z nich umieszczono asteriks (*), którym oznaczono osoby zgłoszone, lecz de facto nieobecne na kongresie. Spośród owych

\footnotetext{
${ }^{7}$ Por. Compte-rendu du premier Congrès International des Études Byzantines (Bukarest, 14-20 April 1924), ed. C. Marinescu, Bukarest 1925 [Reprint: Nendeln (Liechtenstein) 1978], 94-96 (Liste des membres).

${ }^{8}$ Por. Sajdak Jan, w: Biogramy uczonych polskich. Materiały o życiu i działalności czlonków $A U$ w Krakowie, TNW, PAU, PAN, cz. I: Nauki społeczne, z. 3: P-Z, oprac. A. Sródka - P. Szczawiński, Wrocław -Warszawa 1985, 212: „[...] brał czynny udział w obradach komisji patrystycznych i bizantynistycznych podczas międzynarodowych kongresów w Bukareszcie, Belgradzie, Atenach, Monachium i Oslo"; R. Skręt, Sajdak Jan, PSB XXXIV, Wrocław - Warszawa 1992-1993, 333: „Brał udział w kilku międzynarodowych kongresach bizantynistów, od r. 1924 w Bukareszcie poczynając"; por. niżej przyp. 130.

${ }^{9}$ Por. Deuxième Congrès International des Études Byzantines (Belgrad, 11-16 April 1927), sous le haut patronage de sa Majesté le Roi des Serbes, Croates et Slovènes. Compte-rendu par D. Anastasijević - Ph. Granić, Belgrad 1929 [Reprint: Nendeln (Liechtenstein) 1978], s. 200 i 205 (W. Molè), s. 200 i 206 (L. Sternbach), s. 200-201 i 206 (T. Popiel, C. Studziński, H. Święcicki, M. Terecki, K. Zakrzewski), s. 206 (L. Piotrowicz, J. Sajdak). Warto zaznaczyć, że pisownia niektórych nazwisk w aktach kongresowych odbiegała od przyjętej pisowni polskiej: $\mathrm{T}$. Popiel $=\mathrm{Th}$. Popel, C. Studziński = K. Studynskyj, H. Święcicki = I. Świencicki, M. Terecki = M. Teretski.
} 
9-ciu nazwisk asteriksem stygmatyzowano pięć: 1) T. Popiel, 2) L. Sternbach, 3) C. Studziński, 4) H. Święcicki, 5) M. Terecki. Oznacza to, że w rzeczywistości do Belgradu przybyły 4 osoby: 1) W. Molè, 2) L. Piotrowicz, 3) J. Sajdak, 4) K. Zakrzewski. Z tego grona prelekcje miały wygłosić trzy osoby: J. Sajdak - Die Scholiasten des Gregor von Nazianz ${ }^{10}$; W. Molè - Zur Stilentwicklung der älteren byzantinischen Malerei ${ }^{11}$; oraz nieobecny H. Święcic$\mathrm{ki}$ - L'art ancien des pays ukraïniens sur le Dniestre dans l'histoire de l'art byzantinoslave ${ }^{12}$.

Dane przytoczyne przez prof. M. Nystazopoulou-Pélékidou są zatem dalekie od ścisłości. Ekipa polska liczyła bowiem oficjalnie 9 osób, z których do Belgradu przybyły 4 , a referaty wygłosiły de facto dwie osoby. Autorem sprawozdania $\mathrm{z}$ tego kongresu był prof. W. Molè, który stwierdził m.in., że liczba „kongresmenów” dochodziła do 300 osób ${ }^{13}$, podczas gdy tabela nr I mówi o 199 uczestnikach kongresu belgradzkiego.

W obradach III kongresu w Atenach (12-18 X 1930) miało, zdaniem cytowanej wyżej greckiej badaczki, uczestniczyć trzech Polaków. Tym razem liczba polskich uczestników kongresu została podana prawidłowo. Wymaga ona jednak pewnych uściśleń. Polskę w Atenach reprezentowali: prof. dr hab. Witold Klinger (1875-1962) - Uniwersytet Poznański, prof. dr hab. J. Sajdak - Uniwersytet Poznański oraz doc. dr hab. Aleksander Turyn (1900-1981) Uniwersytet Warszawski; przy czym W. Klinger i J. Sajdak mieli na przedmiotowym kongresie status oficjalnych delegatów polskich ${ }^{14}$.

Zgodnie z programem obrad prof. W. Klinger wygłosił prelekcję na temat: Die neugriechischen Fluchmale und die antike Tradition ${ }^{15}$. Natomiast swoisty rekord ,aktywności prelekcyjnej” pobił prawdopodobnie na kongresie ateńskim prof. J. Sajdak, który miał tam mieć aż trzy wystąpienia: 1) w środę, 15 października, w czasie przedpołudniowej sesji (9:00-13:00) sekcji archeolo-

${ }^{10}$ Por. tamże, s. XVI. Referat prof. J. Sajdaka został wygłoszony we wtorek, 12 kwietnia, na sesji przedpołudniowej.

${ }^{11}$ Por. tamże, s. XVII. Prof. W. Molè miał wystapienie w piątek, 15 kwietnia, ok. godz. 9:30.

${ }^{12}$ Por. tamże, s. XVIII. Dr H. Święcicki miał mówić również w piątek, 15 kwietnia, na sesji przedpołudniowej. Jego jednak wystąpienie nie miało się odbyć w tej samej sekcji tematycznej, co referat prof. W. Molè. Przy tytule tego wystąpienia znajduje się podana w nawiasie notka: „(en allemand ou en russe)". Ostatecznie, jak podano wyżej, wystąpienie to nie doszło do skutku z powodu nieobecności prelegenta.

${ }^{13}$ Por. W. Molè, Drugi Międzynarodowy Kongres Studiów Bizantynologicznych w Belgradzie, „Przegląd Współczesny” 6 (1927) t. 22, nr 63, s. 134-137. W tekście tego sprawozdania znajduje się również następująca wzmianka: „Liczba uczestników dochodziła do trzystu” (s. 134).

${ }^{14}$ Por. III' ${ }^{\text {me }}$ Congrès International des Études Byzantines (Athènes 1930). Compte-rendu par A.C. Orlandos, Athènes 1932 [Reprint: Nendeln (Liechtenstein) 1978], s. 417.

15 Por. tamże, s. 19. Wykład ten miał miejsce we wtorek, 14 października, na sesji przedpołudniowej. 
gicznej wygłosił referat pt. Die Miniaturen einer Baseler Handschrift ${ }^{16}$; 2) natomiast w sobotę, 18 października, również w czasie sesji przedpołudniowych, wygłosił dwie prelekcje: jedną w ramach obrad sekcji filologicznej na temat: Was bedeutet «Johannes Geometres»?” (w: Grand Salle de l'Académie) ${ }^{17}$, drugą zaś podczas obrad sekcji historycznej pt. Les poésies lyriques de Jean Géomètre comme source historique (w: Aula de l'Université) ${ }^{18}$. Z kongresu tego nie pozostawiono w polskiej literaturze przedmiotu żadnego sprawozdania.

W IV kongresie w Sofii (9-15 IX 1934) miało, według M. Nystazopoulou-Pélékidou, oficjalnie reprezentować Polskę pięciu badaczy. Tymczasem z akt kongresowych wynika, że było ich tylko czterech: 1) prof. dr hab. W. Molè (UJ), 2) dr Jozafat I. Skruteń (1894-1951) - Towarzystwo Naukowe im. T. Szewczenki (Lwów), 3) dr Hilarion Święcicki - Ukraińskie Muzeum Narodowe we Lwowie, 4) prof. dr hab. Aleksander Turyn (UW) ${ }^{19}$. Błąd greckiej badaczki można tłumaczyć tym, że w przedmiotowych aktach W. Molè figuruje dwa razy: jako oficjalny reprezentant PAU i jako oficjalny przedstawiciel UJ.

Wszyscy oni zapowiedzieli swój czynny udział w kongresie. Ostatecznie oficjalni przedstawiciele nauki polskiej wygłosili trzy referaty: 1) w poniedziałek, 10 września, podczas przedpołudniowej sesji (9:00-13:00) sekcji historycznej prof. A. Turyn przedstawił wywód: Zur Geschichte der griechischen Abstracta in dem europäischen Sprachen ${ }^{20}$; 2) w czwartek, 13 września, w ramach przedpołudniowych obrad sekcji Byzance et le monde slave prof. W. Molè rozważał kwestię: Gibt es ein Problem der Renaissance in der Kunstgeschichte der slavisch-byzantinischen Länder ${ }^{21}$; 3) w czasie tychże czwartkowych, przedpołudniowych obrad tej samej sekcji obok prof. W. Molè miał swoje wystapienie także dr H. Święcicki - Die Kultur- und Kunstbeziehungen Westukraina's mit Byzanz ${ }^{22}$. Nie przybył natomiast do Sofii dr J.I. Skruteń. Jego komunikat pt. 'A $\pi \mathrm{O} \lambda \mathrm{o} \mathbf{\gamma}^{\mathrm{i} \alpha}$ des Mönchpriesters Job gegen die Argumente zugunsten der Lateiner, który miał być wygłoszony w ramach obrad sekcji historycznej, nie został

${ }^{16}$ Por. tamże, s. 27.
${ }^{17}$ Por. tamże, s. 21.
${ }^{18}$ Por. tamże, s. 23.
${ }^{19}$ Por. Actes du IV Congrès International des Études Byzantines (Sofia, septembre 1934), publiés sous la rédaction de B.D. Filov, vol. 2, Sofia 1936 (= „Bulletin de 1'Institute Archéologique Bulgare” 10:1936) [Reprint: Nendeln (Liechtenstein) 1978], s. 311; zob. A. Zięba, Skruteń Jozafat Iwan, PSB XXXVIII, Warszawa - Kraków 1997-1998, 406-407. Jeśli chodzi o stopień naukowy J.I. Skrutnia, warto dodać następujące wyjaśnienie: „W r. 1920 [...] zdał egzamin przed komisją zakonną [Bazylianów], równoznaczny wówczas w kołach kościelnych z uzyskaniem stopnia doktorskiego" (tamże, s. 406).

${ }^{20}$ Por. Actes $d u$ IV Congrès International des Études Byzantines (Sofia, septembre 1934), vol. 1 (= „Bulletin de l'Institute Archéologique Bulgare” 9:1935), s. 12.

${ }^{21}$ Por. tamże, s. 15.

${ }^{22}$ Por. tamże. 
tam odczytany ${ }^{23}$. Należy dodać, że dr H. Święcicki współprzewodniczył wraz z Valerijem A. Pogorélovem (1872-1955) popołudniowym (15:00-18:00) obradom sekcji: Byzance et le monde slave, w piątek, 14 września $^{24}$. Nie sporządzono żadnego sprawozdania $\mathrm{z}$ tego kongresu w języku polskim.

Najwięcej, bo aż ośmiu oficjalnych przedstawicieli Polski przybyło na V Międzynarodowy Kongres Bizantynistów do Rzymu (20-26 IX 1936). Skład tej ekipy był następujący (w porządku alfabetycznym): 1) prof. dr hab. Oskar Halecki (1891-1973) - UW, 2) dr Celina Filipowicz-Osieczkowska (1891-1940) - UJ25, 3) prof. dr hab. J. Sajdak - Uniwersytet Poznański, 4) dr Włodzimierz Sas-Zaloziecki (1896-1959) - UJK we Lwowie, 5) dr J.I. Skruteń - Towarzystwo Naukowe im. T. Szewczenki (Lwów), 6) dr H. Święcicki - Ukraińskie Muzeum Narodowe we Lwowie; 7) prof. dr hab. K. Zakrzewski - UW, 8) prof. dr hab. Tadeusz Zieliński (1859-1944) - UW. Akta kongresowe podają również, że prof. J. Sajdakowi towarzyszyła żona i syn, że dr H. Święcicki przybył wraz z małżonką oraz to, że prof. T. Zieliński był na kongresie w towarzystwie córki ${ }^{26}$.

Ekipa ta wygłosiła następujące referaty: 1) O. Halecki - La Papauté et Byzance au temps du grand schisme d'Occident $\left.{ }^{27}, 2\right) \mathrm{dr}$ C. Filipowicz-Osieczkowska (dwa wystapienia) - Gli avorî a cinque placche e l'arte imperiale romana (Traduzione dal francese di Silvestra T. Sesini) ${ }^{28}$ i Notes sur la décoration du manuscrit grec Czartoryski 1801 et sur l'ornement byzantin (Resumé) ${ }^{29}$, 3) W. Sas-Zaloziecki (dwa wystąpienia) - Ein stilgeschichtlicher Vergleich der Sergius-Bachus Kirche in Konstantinopel und S. Vitale in Ravenna ${ }^{30}$ i Byzanz und Okzident in der bildenden Kunst des Mittelalters ${ }^{31}$, 4) H. Święcicki

${ }^{23}$ Por. tamże, s. 13.

${ }^{24}$ Por. tamże, s. 15.

${ }^{25}$ Por. L. Kalinowski, Osieczkowska z Filipowiczów Celina Anna, PSB XXIV, Wrocław - Warszawa 1979, 329.

${ }^{26}$ Por. Atti del V Congresso Internazionale di Studi Bizantini (Roma, 20-26 settembre 1936), vol. 2: Archeologia e storia dell'arte, liturgia e musica, cronaca del congresso, Studi Bizantini e Neoellenici 6, Roma 1940 [Reprint: Nendeln (Liechtenstein) 1978], s. 610 (O. Halecki), s. 613 (C. Osieczkowska), s. 615 (J. Sajdak), s. 616 (J.I. Skruteń i H. Święcicki), s. 618 (W. Zaloziecki, K. Zakrzewski, T. Zieliński). W przypadku córki prof. T. Zielińskiego chodzi zapewne o Monikę Zielińską (1893-1942). Natomiast żoną prof. J. Sajdaka była od roku 1908 Stefania ,z domu Pazdro (zm. 1966), z którą miał synów: Jana (zm. 1991), adwokata, Stefana (zm. 1964), prawnika, i Jerzego, adwokata”, zob. Skręt, Sajdak Jan, s. 334.

${ }^{27}$ Por. Atti del V Congresso Internazionale di Studi Bizantini (Roma, 20-26 settembre 1936), vol. 1: Storia, filologia, diritto, Studi Bizantini e Neoellenici 5, Roma 1939 [Reprint: Nendeln (Liechtenstein) 1978], s. V i s. 185-187.

${ }^{28}$ Por. Atti del V Congresso Internazionale di Studi Bizantini, vol. 2, s. VI i s. 306-333.

${ }^{29}$ Por. tamże, s. VI i s. 334-339.

${ }^{30}$ Por. tamże, s. 452-455.

${ }^{31}$ Por. tamże, s. 456-459. 
- Die Friedensverträge der Bulgaren und der Russen mit Byzanz. (Ein Beitrag zur Geschichte der Diplomatik und der Politik der Slaven) ${ }^{32}$, 5) T. Zieliński Projet de la création d'un «Corpus scriptorum juris graeco-romani tam canonicis quam civilis»» (en abrégé CSJ) ${ }^{33}$. Z powyższych danych kongresowych wynika, że J. Sajdak, J.I. Skruteń i K. Zakrzewski nie mieli w czasie obrad kongresu żadnej prelekcji. Nie można jednak wykluczyć, że opublikowali oni swe wystąpienia $\mathrm{w}$ innych opracowaniach. Autorowi zaś niniejszego artykułu nie jest znane żadne polskojęzyczne sprawozdanie z kongresu rzymskiego.

Należy nadmienić, że na rok 1939, a dokładnie między 2 a 7 listopada, zaplanowano VI Międzynarodowy Kongres Bizantynistów, który miał się odbyć w Algierze. Jednak wybuch wojny pokrzyżował plany organizatorów i szóste spotkanie bizantynistów odbyło się dopiero w Paryżu w 1948 (27 VII - 2 VIII) roku ${ }^{34}$. W kongresie algierskim miał zamiar wziąć udział prof. dr hab. W. Molè, czego dowodem jest streszczenie jego wystapienia, zamieszczone w wydanych częściowo aktach tego niedoszłego kongresu ${ }^{35}$.

Warto również zwrócić uwagę na całkowitą liczbę uczestników poszczególnych kongresów, która wynika z danych, przytoczonych przez M. Nystazopoulou-Pélékidou (patrz: Tabela I: Suma). I tak w kontekście I kongresu w Bukareszcie V. Tăpkova-Zaimova niuansuje nieco tę statystykę: „Les inscrits étaient au nombre de 64, dont quelques personnes accompagnantes et 4 absents qui firent lire par des collèques leurs communications"36. W przypadku II spotkania w Belgradzie bułgarska badaczka zmienia nieco liczbę uczestników, pisząc o „150 délégués qui ont participé aux six sections” kongresu $^{37}$. Natomiast W. Molè twierdził, że „liczba uczestników dochodziła do trzystu" (por. przyp. 14). Odnośnie IV kongresu w Sofii V. Tăpkova-Zaimova również koryguje swą grecką koleżankę: „On comptait en tout 167 participants (y compris les personnes accompagnantes) et il y a eu 105 exposés dont 8 présentés in absentia" ${ }^{38}$. Różnice te mogą wynikać, jak już wyżej zasygnalizowano, ze sposobu liczenia, np. z przyjęcia podziału zgromadzonych na biernych uczestników (bez odczytu) i prelegentów sensu stricto. Istniała też zwykle spora różnica pomiędzy liczbą oficjalnie zarejestrowanych uczestni-

\footnotetext{
${ }^{32}$ Por. Atti del V Congresso Internazionale di Studi Bizantini, vol. 1, s. VI i s. 322-326.

${ }^{33}$ Por. tamże, s. VIII i s. 735-740.

${ }^{34}$ Por. Tăpkova-Zaimova, Entre deux congrès, s. 46-47.

${ }^{35} \mathrm{~W}$. Molè, Les éléments créateurs de mythes dans l'art byzantin, w: Sixième Congrès International d'Études Byzantines (Alger, 2-7 octobre 1939). Résumés des rapports et communications, préface de G. Millet, Paris 1940, 205-208 ; zob. L. Kalinowski, Wojstaw Molè 1886-1973, „Folia Historiae Artium" 11 (1975) 15 (bibliografia W. Molè).

${ }^{36}$ Por. Tăpkova-Zaimova, Entre deux congrès, s. 39.

${ }^{37}$ Por. tamże, s. 40.

${ }^{38}$ Por. tamże, s. 42.
} 
ków, a liczbą osób de facto obecnych na kongresie. W ten sposób same akta kongresowe nie do końca mogą pełnić funkcję miarodajnego źródła informacji. Z kolei sprawozdania poszczególnych uczestników odwołują się często do ich pamięci, a ta bywa niekiedy zawodna.

\section{POLACY NA KONGRESACH BIZANTYNISTYCZNYCH PO II WOJNIE ŚWIATOWEJ}

Liczba Polaków uczestniczących w kongresach bizantynistycznych po roku 1945 była grosso modo zbliżona do tej, jaką odnotywywano w okresie międzywojennym. Należy przy tym brać pod uwagę zmiany ustrojowe, jakie zaszły po II wojnie światowej, których konsekwencją było z jednej strony duże utrudnienie kontaktów z krajami tzw. Zachodu, z drugiej zaś marginalizacja ideologiczna bizantynistyki. Przedstawiciele tej dyscypliny z bloku wschodniego pojawili się dopiero na X kongresie w Stambule w 1955 roku. Było to niewątpliwie związane ze śmiercią Stalina (1879-1953), która przyniosła pewne osłabienie walki ideologicznej. W kongresie tym wzięły udział trzy tzw. państwa socjalistyczne: Bułgaria, Niemiecka Republika Demokratyczna (NRD) i Związek Socjalistycznych Republik Radzieckich (ZSRR) ${ }^{39}$.

Warto w tym kontekście przypomnieć, że w niektórych powojennych kongresach bizantynistycznych uczestniczyli polscy badacze przedwojenni, którzy po 1945 r. pozostali na obczyźnie. I tak w aktach VI kongresu, który odbył się w Paryżu (27 VII - 2 VIII 1948), figuruje nazwisko byłego adiunkta Uniwersytetu Lwowskiego prof. dr hab. W. Sas-Zalozieckiego ${ }^{40}$, pracującego już wówczas w Austrii, który wygłosił tam prelekcję na temat: Monuments de l'art byzantin en Autriche ${ }^{41}$.

Podobnie rzecz się miała na VII kongresie w Brukseli (4-15 VIII 1948). Jego uczestnikami było dwóch polskich nauczycieli akademickich z okresu II Rzeczypospolitej: 1) prof. dr hab. O. Halecki, który reprezentował wówczas Fordham University i Université de Montréal, wygłaszając referat: Les trois Romes $^{42}$ oraz prof. dr hab. W. Sas-Zaloziecki, będący wówczas pracownikiem uniwersytetu $\mathrm{w}$ Wiedniu, który wygłosił tam prelekcję pt. Les rapports entre Byzance et l'Autriche à l'époque des croisades. ${ }^{43}$.

${ }^{39}$ Por. Nystazopoulou-Pélékidou, Les congrès internationaux des études byzantines, s. 26.

${ }^{40}$ Por. Actes du VI Congrès International d'Études Byzantines (Paris, 27 juillet - 2 août 1948), t. 2, Paris 1951 [Reprint: Nendeln (Liechtenstein) 1978], s. 426. Pisownia nazwiska w aktach kongresu: W. Sas-Zaloziecky.

${ }^{41}$ Por. tamże, s. 365-372.

${ }^{42}$ Por. VII Congrès International des Études Byzantines (Bruxelles, 4-15 août 1948), Bruxelles 1948,8 .

${ }^{43}$ Por. tamże, s. 12. Pisownia nazwiska w aktach kongresu: W. Sas-Zaloziecky. 
Po II wojnie światowej Polska była reprezentowana oficjalnie po raz pierwszy dopiero w XI kongresie w Monachium (15-20 IX 1958) ${ }^{44}$. Jako oficjalny reprezentant PRL-u figuruje w aktach kongresu prof. dr hab. Kazimierz F. Kumaniecki (1905-1977) - UW ${ }^{45}$. W aktach tych nie ma jednak żadnego śladu jego ewentualnego wystapienia. Nie ma również w aktach kongresowych śladu udziału prof. dr hab. J. Sajdaka, choć biografowie uczonego sugerują jego uczestnictwo w tym wydarzeniu (por. przyp. 9). Nie należy też zapominać o tych Polakach, czy też obywatelach II Rzeczypospolitej, którym po roku 1945 przyszło pracować poza granicami kraju. Z tej grupy w kongresie monachijskim uczestniczył prof. dr hab. O. Halecki ${ }^{46}$, który wystąpił z referatem na temat: Angora, Florence, Varna, and the fall of Constantinople ${ }^{47}$. Drugim reprezentantem był wspomniany już kilkakrotnie prof. dr hab. W. Sas-Zaloziecki, pracujący wtedy na austriackim uniwersytecie w $\mathrm{Grazu}^{48}$.

Na kolejny XII kongres w Ochrydzie (10-16 IX 1961) przybyły znad Wisły w charakterze oficjalnej reprezentacji trzy osoby: doc. dr hab. Halina Evert-Kappesowa (1904-1985) - UŁ ${ }^{49}$, prof. dr hab. W. Molè (UJ) ${ }^{50}$ i mgr Tadeusz Wasilewski (1933-2005) - UW ${ }^{51}$. Doc. H. Evert-Kappesowa wygłosiła tam komunikat pt. Quelques remarques sur la colonisation slave ${ }^{52}$, zaś prof. W. Molè wystąpił również z komunikatem, którego tytuł brzmiał: Les fresques de l'église de $S^{\text {te }}$ Sophie à Ochride du XI siècle, monument de l'humanisme de l'art byzantin ${ }^{53}$. Natomiast rozpoczynający wówczas swą karierę naukową

${ }^{44}$ Por. Nystazopoulou-Pélékidou, Les congrès internationaux des études byzantines, s. 26-27. Obok Polski udział w kongresie brały także: Bułgaria, Czechosłowacja, NRD, Węgry i ZSRR; zob. też Kronika - XI Międzynarodowy Kongres Bizantynologów, „Przegląd Historyczny” 49 (1958) nr 1, s. 196. Jest to tylko informacja o mającym się odbyć kongresie.

${ }^{45}$ Por. Akten des XI. Internationalen Byzantinistenkongresses, München 1958, hrsg. von F. Dölger-H.G. Beck, München 1960, s. XXI.

${ }^{46}$ Por. tamże, s. XX.

${ }^{47}$ Por. tamże, s. 217-220.

${ }^{48}$ Por. tamże, s. XXIII. Pisowania nazwiska w aktach kongresu: W. Sas-Zaloziecky.

${ }^{49}$ Por. W. Ceran, Les études byzantines au cours des 25 années de la Pologne Populaire, w: L'Antiquité classique au cours des 25 années de la République Populaire de Pologne, Wrocław - Warszawa 1974, 124; tenże, Bizantynistyka w Polsce Ludowej w okresie 25-lecia, w: Batkanistyka polska. Materiały z posiedzeń naukowych Komisji Bałkanistycznej przy Komitecie Słowianoznawczym PAN w latach 1972-1973, Wrocław -Warszawa 1974, s. 13, przyp. 34.

${ }^{50}$ Por. L. Kalinowski, Molè Wojsław, PSB XXI, Wrocław - Warszawa 1976, 619.

${ }^{51}$ Por. W. Ceran - H. Evert-Kappesowa, Les études byzantines en Pologne, „Byzantion” 44 (1974) 546, przyp. 1; Ceran, Les études byzantines au cours des 25 années, s. 126, przyp. 47; tenże, Bizantynistyka w Polsce Ludowej, s. 15, przyp. 48.

${ }^{52}$ Por. Actes du XIIe Congrès International d'Études Byzantines (Ochride, 10-16 septembre 1961), t. 2, Belgrad 1964, 79-81.

${ }^{53}$ Por. XII Congrès International des Études Byzantines (Ochride 1961). Résumés des communications, Belgrad 1961, 76. 
mgr T. Wasilewski podjął w swym wystapieniu zagadnienie: Les titres de duc, de catépan et de promoétès dans l'Empire Byzantine du IX jusqu'au XII ${ }^{e}$ siècle $^{54}$. Na temat uczestnictwa Polaków w tym kongresie istnieje w rodzimej literaturze kilka wzmianek (por. przyp. 50-52).

*

W XIII kongresie w Oksfordzie (5-10 IX 1966) z Polski brały oficjalnie udział dwie osoby: doc. dr hab. H. Evert-Kappesowa (UŁ) ${ }^{55}$ i mgr Beatrysa Hirszenberg (ur. 1910) - Muzeum Budownictwa Ludowego w Sanoku (gdzie pracowała od 1964 do 1966) $)^{56}$; ta ostatnia jest również autorką krótkiego sprawozdania z tego wydarzenia ${ }^{57}$. Wystapienie (najprawdopodobniej chodzi o komunikat) doc. H. Evert-Kappesowej pt. Société et organisation intérieure au XI siècle" znajduje się w aktach kongresowych ${ }^{58}$. Natomiast o pobycie w Oxfordzie B. Hirszenberg i o komunikacie autorstwa Wojciecha Kurpika ${ }^{59}$, który tam wygłosiła, informuje wyłącznie napisane przez nią samą sprawozdanie (por. przyp. 58).

W obradach XIV kongresu w Bukareszcie (6-12 IX 1971) brała oficjalnie udział pięcioosobowa grupa badaczy polskich: 1) mgr B. Hirszenberg (nie udało się ustalić, jaką instytucję wówczas reprezentowała), 2) prof. dr hab. Oktawiusz Jurewicz (UW), 3) dr Janina Kłosińska (1920-2007) - Muzeum Narodowe w Krakowie, 4) doc. dr hab. T. Wasilewski (UW) i 5) dr Anna Różycka-Bryzek (1928-2005) - UJ ${ }^{60}$. W kongresie tym brała także udział dr

${ }^{54}$ Por. Actes du XII Congrès International d'Études Byzantines, s. 233-239.

${ }^{55}$ Por. Ceran - Evert-Kappesowa, Les études byzantines en Pologne, s. 543, przyp. 2; Ceran, Les études byzantines au cours des 25 années, s. 124; tenże, Bizantynistyka w Polsce Ludowej, s. 13; tenże, Profesor dr Halina Evert-Kappesowa i jej dorobek w badaniach nad Bizancjum, „Eos” 75 (1987) fasc. 2, s. 238.

56 Informacje te pochodzą z zasobów archiwalnych Muzeum Budownictwa Ludowego w Sanoku.

${ }^{57}$ Por. B. Hirszenberg, XIII Międzynarodowy Kongres Studiów Bizantyńskich, „Materiały Muzeum Budownictwa Ludowego w Sanoku” 4 (1966) 80: „W skład uczestników tegorocznego Kongresu, w którym brało udział 600 osób z całego świata, weszła także Beatrysa Hirszenberg przedstawicielka Muzeum Budownictwa w Sanoku. Wygłoszony przez nią komunikat, przygotowany przez mgr-a Wojciecha Kurpika, pt. Próby ustalenia na podstawie właściwości technicznych i stylistycznych pochodzenia niektórych ikon z poludniowo-wschodnich okolic Polski wzbudził zainteresowanie [...]". Sprawozdanie to nie jest cytowane w: W. Ceran, Historia i bibliografia rozumowana bizantynologii polskiej (1800-1998), t. 1-2, Byzantina Lodziensia 6, Łódź 2001.

${ }^{58}$ Por. Proceedings of the XIII I International Congress of Byzantine Studies (Oxford, 5-10 September 1966), ed. by J.M. Hussey - D. Obolensky - S. Runciman, London - Oxford 1967, 397-400.

${ }^{59}$ Chodzi o prof. dr. W. Kurpika, który od roku 1962 pracował przez pewien czas w Muzeum Budownictwa Ludowego w Sanoku, por. http://pl.wikipedia.org/wiki/Wojciech_Kurpik [sprawdzono: 20.05.2012].

${ }^{60}$ Por. Actes du XIVE Congrès International des Études Byzantines (Bucarest, 6-12 septembre 1971), publiés par les soins de M. Berza - E. Stănescu, vol. 1, Bucareşti 1974, 13-28 (Liste des participants). 
Wanda Wolska-Conus (1919-2012), lecz reprezentowała tam bizantynistykę francuską ${ }^{61}$. W aktach kongresowych można znaleźć tylko tekst komunikatu T. Wasilewskiego - Le katepanikion et le duché de Paristrion au XI ${ }^{e}$ siècle ${ }^{62}$ oraz referat W. Wolskiej-Conus - À propos des Scolies de Stéphanos à la Rhétorique d'Aristote: l'auteur, l'oeuvre, le milieu ${ }^{63}$. Nikt z Polaków uczestniczących w kongresie nie napisał sprawozdania z jego obrad.

$$
*
$$

XV kongres, który odbył się w Atenach (5-11 IX 1976), miał wśród swych uczestników szóstkę Polaków: 1) dr Waldemar Ceran (1936-2009) - UŁ, 2) prof. dr hab. H. Evert-Kappesowa (UŁ), 3) mgr B. Hirszenberg (nie udało się ustalić, jaką instytucję wówczas reprezentowała), 4) doc. dr hab. Irena Malinowska-Kwiatkowska (1925-1994) - UJ, 5) doc. dr hab. Andrzej Poppe (ur. 1926) - UW i 6) doc. dr hab. T. Wasilewski (UW) ${ }^{64}$.

W aktach tego kongresu znajdują się dwa streszczenia komunikatów, wygłoszonych przez polskich uczestników tego spotkania. Autorką pierwszego $\mathrm{z}$ nich jest B. Hirszenberg - Quelques remarques sur l'architecture non-typique d'une icône du Musée de Jaslo, Pologne $e^{65}$ (w aktach jest również wersja angielska tegoż komunikatu: About atypical architecture on a icon of St. Nicholas $\left.^{66}\right)$. Natomiast drugi komunikat pochodził od I. Malinowskiej-Kwiatkowskiej - Byzantine Law as viewed by Polish legal historians ${ }^{67}$. W programie kongresu figuruje też francuska wersja tego komunikatu - Le droit byzantin vu

${ }^{61}$ Por. tamże.

${ }^{62}$ Por. Actes du XIV Congrès International des Études Byzantines, vol. 2, Bucareşti 1975 , 641-645.

${ }^{63}$ Por. Actes du XIV Congrès International des Études Byzantines, vol. 3, Bucareşti 1976, 599606. Nieco inny tytuł tego komunikatu figuruje w: XIV Congrès International des Études Byzantines (Bucarest, 6-12 septembre 1971). Resumés - Communications, Bucareşti 1971, 313, gdzie brzmi tam następująco: Stéphanos - auteur des Scolies à la Rhétorique d'Aristote: essai de datation et d'identification.

${ }^{64}$ Por. $X V^{e}$ Congrès International d'Études Byzantines. Programme, Athènes 1976, s. 22 (A. Poppe), s. 24 (B. Hirszenberg), s. 40 (I. Malinowska-Kwiatkowska); Actes du XVe Congrès International d'Études Byzantines (Athènes, Septembre 1976), vol. 1: Chronique du Congrès. Art et archéologie, Athènes 1979, s. 23 (W. Ceran), s. 60 (B. Hirszenberg), s. 65 (T. Wasilewski), s. 75 (I. Malinowska-Kwiatkowska).

${ }^{65}$ Por. $X V^{e}$ Congrès International d'Études Byzantines. Résumés des communications, vol. II/B: III. Art et archéologie (Athènes, 5-11 septembre 1976), Athènes 1981 - nie ma numeracji stron, a tylko kolejność alfabetyczna nazwisk. Komunikat ten został wygłoszony w środę, 8 września, ok. godz. 18:30 - Actes du XV Congrès International d'Études Byzantines (Athènes, Septembre 1976), vol. 1: Chronique du Congrès, s. 60.

${ }^{66}$ Por. Actes du XV Congrès International d'Études Byzantines (Athènes, Septembre 1976), vol. II/A: Art et archéologie. Communications A, Athènes 1981, 203-206.

${ }^{67}$ Por. XVe Congrès International d'Études Byzantines. Résumés des communications, I: Histoire; II: Langue, littérature, philologie; IV: Pensée, philosophie, histoire des idées; V: Cypre dans le monde byzantin (Athènes, 5-11 septembre 1976), Athènes 1980 - nie ma numeracji stron, a tylko kolejność alfabetyczna nazwisk. 
par les historiens $d u$ droit en Pologne ${ }^{68}$ oraz wystapienie T. Wasilewskiego La disparition des tagmata impériaux à Byzance dans la deuxième moitié du $X I^{e}$ siècle ${ }^{69}$.

O udziale Polaków w tym kongresie wspominają autorzy polskiego sprawozdania $\mathrm{z}$ tego wydarzenia ${ }^{70}$. Istnieje jednak wyraźna rozbieżność, co do liczby polskich uczestników tego kongresu, pomiędzy danymi oficjalnymi (por. przyp. 65), a sprawozdaniem W. Cerana (por. przyp. 71), gdzie widnieją tylko trzy nazwiska (brak B. Hirszenberg, I. Malinowskiej-Kwiatkowskiej i A. Poppe). Można to tłumaczyć tym, że nie wszystkie osoby, które zgłosiły swój udział w kongresie, przybyły do Aten.

Nieco większa ekipa z Polski przybyła w roku 1981 do Wiednia (4-9 X 1981), aby wziąć udział w XVI kongresie bizantynistów. W jej skład wchodzili: 1) doc. dr hab. W. Ceran (UŁ), 2) dr Helena Cichocka (UW), 3) dr Włodzimierz Godlewski (UW), 4) prof. dr hab. O. Jurewicz (UW), 5) I. Malinowska-Kwiatkowska (UJ), 6) doc. dr hab. Andrzej Poppe (UW), 7) dr hab. A. Różycka-Bryzek (UJ), 8) doc. dr hab. T. Wasilewski (UW) ${ }^{71}$.

$\mathrm{W}$ aktach kongresowych znajdują się natomiast wystąpienia ( $\mathrm{w}$ formie ko-

${ }^{68}$ Por. Actes $d u X V^{e}$ Congrès International d'Études Byzantines (Athènes, Septembre 1976), vol. I: Chronique du Congrès, s. 75. Komunikat ten został wygłoszony w sobotę, 11 września, ok. godz. 11:45.

${ }^{69}$ Por. tamże, s. 65. Komunikat ten został wygłoszony w piątek, 10 września, na sesji przedpołudniowej.

${ }^{70}$ Por. W. Ceran - H. Evert-Kappesowa, XV Międzynarodowy Kongres Bizantynistów (Ateny, 5-11 IX 1976), „Studia Źródłoznawcze” 23 (1978) 265-268. W kontekście niniejszego sprawozdania ważna jest następująca uwaga Autorów: „Polskich uczestników Kongresu było tylko troje: doc. dr Tadeusz Wasilewski z Uniwersytetu Warszawskiego i niżej podpisani [tj. W. Ceran i H. Evert-Kappesowa] z Uniwersytetu Łódzkiego" (s. 268).

${ }^{71}$ Por. XVI. Internationaler Byzantinistenkongress. Programm, Wien 1981, s. 44 (W. Godlewski), s. 46 (I. Malinowska-Kwiatkowska); XVI. Internationaler Byzantinistenkongress. Verzeichnis der Theilnehmer (Wien, 4.-9. Oktober 1981), Wien 1981; zob. też W. Ceran, XVI Międzynarodowy Kongres Bizantynistów (Wiedeń, 4-9 X 1981), „Studia Źródłoznawcze” 29 (1985) 255-258. Sprawozdanie to zawiera kilka ważnych danych statystycznych: „W Kongresie wzięło udział 843 bizantynistów (wedle danych sekretariatu). [...]. Wygłoszono ogółem 33 referaty i 337 komunikatów" (s. 255); „Z polskich bizantynistów udział w Kongresie wzięli: Waldemar Ceran, Helena Cichocka, Oktawiusz Jurewicz, Andrzej Poppe, Anna Różycka-Bryzek, Tadeusz Wasilewski” (s. 258); Helena Cichocka, XVI Międzynarodowy Kongres Bizantynistów (Wiedeń, 4-9 X 1981), „Meander” 37 (1982) nr 6, 277-279. Tekst tej relacji zawiera następujące dane: „W kongresie wzięło udział około 1000 bizantynistów z całego świata, w tym 6 bizantynistów polskich: prof. dr hab. Oktawiusz Jurewicz, doc. dr hab. Tadeusz Wasilewski, doc. dr hab. Waldemar Ceran, doc. dr hab. Andrzej Poppe, dr hab. Anna Różycka-Bryzek, dr Helena Cichocka" (s. 278). Podobnie jak w przypadku Aten, również i tutaj liczba polskich uczestników kongresu podane w oficjalnych wykazach kongresowych różni się od danych przytoczonych w sprawozdaniu prof. W. Cerana. W tym ostatnim brak mianowicie nazwiska W. Godlewskiego i I. Malinowskiej-Kwiatkowskiej. Jest możliwe, że osoby te, choć oficjalnie zgłosiły swój udział w kongresie, de facto do Wiednia nie przybyły, por. przyp. 65 i 71. 
munikatów) następujących polskich prelegentów: 1) H. Cichocka - La prose rythmique de Zosime ${ }^{72}$, 2) W. Godlewski - The Throne Hall in Old Dongola $(\text { Sudan })^{73}$, 3) I. Malinowska-Kwiatkowska - Das Strafrecht der russischen Kodifikation v. J. 1649 und das byzantinische Recht ${ }^{74}$, 4) A. Różycka-Bryzek Corpus of Icon Painting from Little Poland ${ }^{75}$, 5) T. Wasilewski - Le couronnement d'un prince-vassal à Byzance et sa signification juridique et politique ${ }^{76}$.

Polscy uczestnicy kongresu wiedeńskiego napisali dwa sprawozdania $\mathrm{z}$ tego wydarzenia (por. przyp. 72). Warto w tym miejscu zwrócić uwagę na fakt, iż między oficjalnymi danymi zachowanymi w aktach kongresu, a polskimi sprawozdaniami istnieją pewne rozbieżności: te ostatnie pomijają bowiem udział w wiedeńskich obradach W. Godlewskiego i I. Malinowskiej-Kwiatkowskiej (por. przyp. 72). Jest możliwe, że osoby te nadesłały swe komunikaty, natomiast osobiście nie brały udziału w obradach kongresowych.

XVII kongres odbył się w Waszyngtonie (3-8 VIII 1986). Polskę reprezentowali tam trzej badacze: 1) dr Adam T. Łukaszewicz (UW), 2) prof. dr hab. A. Poppe (UW), 3) prof. dr hab. T. Wasilewski (UW). Pierwszy z nich wygłosił komunikat na temat: A travesty of Signa Christi reconsidered ${ }^{77}$. Z kolei prof. A. Poppe omówil, również w formie komunikatu, zagadnienie The enthronement of the Prince in Kievan Rus ${ }^{78}$. Wreszcie T. Wasilewski poświęcił swe krótkie wystąpienie kwestii Les origines slaves des frères de Thessalonique, Constantin et Methode ${ }^{79}$. Z kongresu tego nie istnieje żadne sprawozdanie w języku polskim.

${ }^{72}$ Por. XVI. Internationaler Byzantinistenkongress. Résumés der Kurzbeiträge, Wien 1981, 5.3; XVI. Internationaler Byzantinistenkongress (Wien, 4.-9. Oktober 1981). Akten, II. Teil, 3. Teilband: Kurzbeiträge: 5. Funktionen und Formen der byzantinischen Literatur, 6. Realienkunde-materielle Kultur, Jahrbuch der Österreichischen Byzantinistik 32/3, Wien 1982, 345-354.

${ }^{73}$ Por. XVI. Internationaler Byzantinistenkongress. Akten, II. Teil, 4. Teilband: Kurzbeiträge: 7. Buch und Gesellschaft in Byzanz, 8. Theologie und Philosophie in der Palaiologenzeit, 9. Byzantinische Architektur, Jahrbuch der Österreichischen Byzantinistik 32/4, Wien 1982, 569-574.

${ }^{74}$ Por. XVI. Internationaler Byzantinistenkongress. Résumés der Kurzbeiträge, 4.3; XVI. Internationaler Byzantinistenkongress. Akten, II. Teil, 2. Teilband: Kurzbeiträge: 4. Soziale Strukturen und ihre Entwicklung, Jahrbuch der Österreichischen Byzantinistik 32/2, Wien 1982, 303-311.

${ }^{75}$ Por. XVI. Internationaler Byzantinistenkongress. Akten, I. Teil: Hauptreferate, Beiheft: Meldungen zu den Plenarsitzungen 1-3, Jahrbuch der Österreichischen Byzantinistik. Beiheft 31, Wien 1981, 3.2.

${ }^{76}$ Por. XVI. Internationaler Byzantinistenkongress. Akten, II. Teil, 2. Teilband: Kurzbeiträge: 4. Soziale Strukturen und ihre Entwicklung, s. 373-381.

${ }^{77}$ Por. The $17^{\text {th }}$ International Byzantine Congress, 1986. Abstract of short papers (Washington D.C., 3-8 August 1986), ed. G. Vikan, Baltimore 1986, 201-202.

${ }^{78}$ Por. tamże, s. 272-274.

${ }^{79}$ Por. tamże, s. 382-383; zob. też. 3.В. Удальцова-С.П. Карпов-Г.Г. Литаврин - И.П. Медведев - К.В. Хвостова - Я.Н. Шапов - С.А. Иванов, XVII Международный Конгресс Византинистов в Вашингтоне, „Византийский Временник” 49 (1988) s. 249 i 250. 
XVIII kongres mający swe obrady w Moskwie (8-15 VIII 1991) ${ }^{80}$ gościł oficjalnie ośmiu polskich uczestników. Byli nimi w porządku alfabetycznym: 1) dr Andrzej Biernacki (UAM), 2) dr Helena Cichocka (UW), 3) dr Małgorzata Dąbrowska (UŁ), 4) mgr Waldemar Deluga (Muzeum Narodowe w Warszawie), 5) prof. dr hab. A. Poppe (UW), 6) doc. dr hab. Maciej Salamon (UJ), 7) prof. dr hab. Tadeusz Ulewicz (1917-2012) - UJ, 8) prof. dr hab. T. Wasilewski $(\mathrm{UW})^{81}$. Z programu kongresu wynika, że prof. T. Wasilewski miał w Moskwie dwa wystapienia: jeden z referatów wiodących na sesji plenarnej oraz komunikat w ramach sekcji Византия и славянские государства. Туtuł jego referatu brzmiał: Обращенная в христианство Русь в византийской семье правителей и народов ${ }^{82}$, natomiast temat jego komunikatu był następujący: La place de l'émpire bulgare dans le monde byzantin pendant le haut Moyen $\hat{A g} e^{83}$. Pozostali członkowie polskiej ekipy wygłosili komunikaty w ramach obrad sekcji tematycznych. Dr A. Biernacki wystapił z prelekcją na temat: Римская и ранневизантийская архитектура и градоустройст$60^{84}$, dr M. Dąbrowska wygłosiła komunikat: L'Éthos de la famille de la cour impériale des Paléologues selon le témoignage de Théodore de Montferrat ${ }^{85}$. Mgr W. Deluga omówił kwestię: Les 'Praznik' en tant qu'élément de l'icono$\operatorname{stase}^{86}$. Doc. M. Salamon poruszył w swym komunikacie zagadnienie: Greek

${ }^{80} \mathrm{Za}$ udostępnienie akt kongresu moskiewskiego dziękuję bardzo serdecznie prof. dr hab. Maciejowi Salamonowi.

${ }^{81}$ Por. ХVIII Международный Конгресс Византинистов. Список участников (Москва, 8-15 VIII. 1991), Москва 1991, s. 19 (A. Biernacki), s. 32 (H. Cichocka), s. 35 (M. Dąbrowska), s. 38 (W. Deluga), s. 131 (A. Poppe), s. 139 (M. Salamon), s. 172 (T. Wasilewski), s. 200 (nazwiska wszystkich siedmiu polskich uczestników kongresu). W spisie uczestników kongresu brakuje nazwiska prof. T. Ulewicza. Pojawia się ono natomiast w programie kongresu oraz w tomie zawierającym streszczenia wygłoszonych w Moskwie komunikatów. Co do dr H. Cichockiej i prof. A. Poppe to ich nazwiska figurują tylko i wyłącznie w spisie uczestników.

82 Por. ХVIII Международный Конгресс Византинистов. Программа (Москва, 8-15 VIII 1991), Москва 1991, 68. Referat z sesji plenarnej został wydrukowany w całości w: XVIII Международный Конгресс Византинистов. Пленарные доклады, Московский Государсвенный Университет им. М.В. Ломоносова (8-15 Августа 1991), Москва, 1991, 8-26.

${ }^{83}$ Por. XVIII Международный Конгресс Византинистов. Программа, s. 212. Streszczenia tego komunikatu nie ma w aktach kongresowych.

${ }^{84}$ Por. XVIII Международный Конгресс Византинистов. Программа, s. 41. Streszczenia tego komunikatu nie ma jednak w odpowiednim tomie akt postkongresowych.

${ }^{85}$ Por. XVIII Международный Конгресс Византинистов. Программа, s. 143. Streszczenie przedmiotowego komunikatu znajduje się w: XVIII Международный Конгресс Византинистов. Резюме сообщений (8-15 Августа 1991), Московский Государсвенный Университет им. М.В. Ломоносова, t. 1: A-K, Москва 1991, 265-266.

${ }^{86}$ Por. ХVIII Международный Конгресс Византинистов. Программа, s. 184. Streszczenie niniejszego komunikatu zostało opublikowane w: XVIII Международный Конгресс Византинистов. Резюме сообщений, t. 1, s. 279. 
elements in the inscriptions of Byzantine coins in the sixth century" ${ }^{\prime 87}$. Wreszcie prof. T. Ulewicz przybliżył słuchaczom temat: A hundred years of philological studies on Humanism and the Latin Renaissance in Poland ${ }^{88}$.

$\mathrm{Z}$ grona polskich badaczy pracujących zagranica, dwa komunikaty wygłosiła Danuta M. Górecki, reprezentująca The Graduate School of Library and Information Science (University of Illinois at Urbana-Champaign, USA): 1),Boris A. Panchenko: some observations on his contributions to studies of Byzantine peasantry" ${ }^{89}$; 2) Statute of limitations in the Macedonian Novels ${ }^{90}$. W polskiej literaturze przedmiotu istnieją dwa krótkie sprawozdania z tego wydarzenia. Autorami pierwszego są M. Dąbrowska i M. Salamon ${ }^{91}$, natomiast drugą relację napisał dr hab. Bazyli Degórski ${ }^{92}$. Pomiędzy oficjalną listą uczestników z Polski, która wymienia 8 osób, a sprawozdaniem autorstwa M. Dąbrowskiej i M. Salamona mówiącym o 4 Polakach w Moskwie, zachodzi dość wyraźna rozbieżność (por. przyp. 92). Różnicę tę można tłumaczyć tym, że autorzy przedmiotowego sprawozdania wzięli pod uwagę tylko Polaków, którzy de facto brali udział w kongresie, podczas gdy oficjalny wykaz uczestników podaje wszystkich, którzy znacznie wcześniej zgłosili swój udział, lecz z jakichś przyczyn nie przybyli do Moskwy.

Bardzo skromnie prezentowała się ekipa polska na XIX kongresie w Kopenhadze (18-24 VIII 1996) ${ }^{93}$. Nasz kraj reprezentowały na nim de facto tylko dwie osoby: prof. UJ dr hab. M. Salamon (UJ) i dr hab. M. Dąbrowska (UŁ). Natomiast spośród Polaków pracujących poza granicami kraju były obecne cztery osoby: dr Ewa Balicka-Witakowska i dr Władysław Ducz-

${ }^{87}$ Por. XVIII Международный Конгресс Византинистов. Программа, s. 123. Streszczenie komunikatu znajduje się w: XVIII Международный Конгресс Византинистов. Резюме сообщений, t. 2: L-Z, s. 980-981.

${ }^{88}$ Por. XVIII Международный Конгресс Византинистов. Программа, s.79. Streszczenie tego wystapienia wydrukowano w: ХVIII Международный Конгресс Византинистов. Резюме сообщений, t. 2, s. 1191-1193.

89 Por. ХVIII Международный Конгресс Византинистов. Резюме сообщений, t. 1, s. $379-380$.

${ }^{90}$ Por. tamże, s. 381-382.

${ }^{91}$ Por. M. Dąbrowska - M. Salamon, Sprawozdanie z XVIII Międzynarodowego Kongresu Bizantynistów w Moskwie, „Studia Źródłoznawcze” 35 (1994) 151-152. Tekst ten przekazuje kilka danych statystycznych: „Kongres odbył się w dniach 8-15 sierpnia 1991 r. i zgromadził około 1500 uczestników z wielu krajów świata” (s. 151); „Stronę polską na kongresie reprezentowali: [...] prof. T. Wasilewski [UW], prof. M. Salamon (Uniwersytet Jagielloński), dr M. Dąbrowska (Uniwersytet Łódzki) i mgr W. Deluga (Muzeum Narodowe w Warszawie)" (s. 152); por. przyp. 65, 71 i 72.

92 Por. B. Degórski, XVIII Międzynarodowy Kongres Studiów Bizantyńskich (Moskwa, 8-14 VIII 1991), VoxP 11-12 (1991-1992) t. 20-23, 519-524. Sprawozdanie to pochodzi „z drugiej ręki” i w swoim tytule zawiera błędną datę zakończenie kongresu (14 VIII), zamiast 15 VIII.

$93 \mathrm{Za}$ udostępnienie akt kongresu kopenhaskiego dziękuję serdecznie prof. Maciejowi Salamonowi. 
ko, reprezentujący Szwecję, a ściślej Uniwersytet w Uppsali; dr Zbigniew T. Fiema występował jako przedstawiciel American Center of Oriental Research (Amman, Jordania). Natomiast dr D.M. Górecki reprezentowała The Graduate School of Library and Information Science (University of Illinois at Urbana-Champaign, USA).

Komunikat wygłoszony przez prof. M. Salamona nosił tytuł: Justinian's coins in Central Europe ${ }^{94}$; tenże przedstawiciel Polski moderował także wraz z prof. dr hab. Günterem Prinzingiem Round Table B i jako taki wygłaszał również słowo wprowadzające w obrady tej sekcji ${ }^{95}$. Natomiast dr hab. M. Dąbrowska wygłosiła komunikat: From Poland to Tenedos. The project of using the Teutonic Order in the fight against the Turks after the fall of Constantinople ${ }^{96}$. Jeśli chodzi o prelekcje wygłoszone przez Polaków pracujących poza krajem, to rzecz przedstawia się następująco: dr E. Balicka-Witakowska przedstawiła komunikat nt. L'importance du matériel éthiopien pour les études sur l'art byzantin: le cas de l'église Gânnâtâ Maryam (XIII siècle) et son ensemble de peintures murales ${ }^{97} ; \mathrm{dr} \mathrm{W}$. Buczko miał referat na sesji plenarnej pt. Viking Sweden and Byzantium - an archaeologists version ${ }^{98}$; dr Z.T. Fiema wygłosił komunikat dotyczący The culture history of the Byzantine ecclesiastical complex at Petra, Jordan ${ }^{99}$; a dr D.M. Górecka przedstawiła komunikat The language of the Macedonian Novels on preemption: green light for Circumvention of the $\mathrm{Law}^{100}$. Z kongresu tego nie ma w literaturze polskiej żadnego komunikatu.

${ }^{94}$ Por. Byzantium. Identity, image, influence. XIX International Congress of Byzantine Studies, University of Copenhagen (18-24 August 1996). Index of Colloquia as of July 15, 1996. Abstracts of Communications. Index of authors, ed. by K. Fledelius, Copenhagen 1996, nr 8501 (nie ma tam stron, lecz kod).

${ }^{95}$ Por. G. Prinzing - M. Salamon, Byzanz und Ostmitteleuropa 950-1453, w: Byzantium. Identity, Image, Influence. XIX International Congress of Byzantine Studies (University of Copenhagen, 18-24 August 1996). Major Papers, ed. by K. Fledelius in cooperation with P. Schreiner, Copenhagen 1996, 493.

${ }^{96}$ Referat ten został opublikowany w: Byzanz und Ostmittelauropa 950-1453. Beiträge zu einer Table Ronde des XIX. International Congress of Byzantine Studies (Copenhagen 1996), hrsg. von G. Prinzing - M. Salamon, Mainzer Veröffentlichungen zur Byzantinistik 3, Wiesbaden 1999, 165 176. Za powyższe informacje dziękuję bardzo prof. UŁ dr hab. M. Dąbrowskiej.

${ }^{97}$ Por. Byzantium. Identity, image, influence. XIX International Congress of Byzantine Studies, (University of Copenhagen, 18-24 August 1996). Index of Colloquia as of July 15, 1996. Abstracts of Communications, nr 1243 (nie ma tam stron, lecz kod).

${ }^{98}$ Por. Byzantium. Identity, image, influence. XIX International Congress of Byzantine Studies, (University of Copenhagen, 18-24 August 1996). Major Papers, s. 193-200.

${ }^{99}$ Por. Byzantium. Identity, image, influence. XIX International Congress of Byzantine Studies, (University of Copenhagen, 18-24 August 1996). Index of Colloquia as of July 15, 1996. Abstracts of Communications, $\mathrm{nr} 4121$ (nie ma tam stron, lecz kod).

${ }^{100}$ Por. tamże, nr 2114 (nie ma tam stron, lecz kod). 
XX kongres w Paryżu (19-25 VIII 2001) ${ }^{101}$ zgromadził nieco szersze grono prelegentów z Polski. Należeli do nich: 1) prof. UŁ dr hab. M. Dąbrowska (UŁ), 2) dr Andrzej J. Freilich (KUL), 3) dr Mirosław P. Kruk (Muzeum Narodowe w Krakowie), 4) mgr Magdalena Łaptaś (UKSW), 5) dr Jan Prostko-Prostyński (UAM), 6) mgr Grzegorz Rostkowski (PAN Warszawa), 7) prof. UJ dr hab. M. Salamon (UJ), 8) prof. dr hab. T. Wasilewski (UW). W kongresie tym brała również udział dr Ewa Balicka-Witakowska, absolwentka UW, która na poprzednim kongresie w Kopenhadze reprezentowała uniwersytet w Uppsali.

Wszyscy Polacy wygłosili w Paryżu komunikaty. Prof. M. Dąbrowska wystapiła z prelekcją na temat: Byzance dans la conscience des Polonais. Sources de stéréotypes ${ }^{102}$; dr A.J. Frejlich mówił o Byzantine theology of icon as a main argument in the catholic-protestant discussion on the problem of the cult of images in the 16th century Poland ${ }^{103}$; dr M.P. Kruk wygłosił komunikat pt. Les icônes Ruthéniennes de la Vierge Marie avec le Christ Emmanuel du $X V^{e}$ et $d u X V I^{e}$ siècle ${ }^{104}$; mgr M. Łaptaś omówiła kwestię: The loros as part of the archangels dress in Faras cathedral (Nubia) ${ }^{105}$; dr J. Prostko-Prostyński przybliżył audytorium kongresowemu problem: Regesten der Senatssitzungen im spätrömischen Reich von Diokletian bis Justinian. Die Anlage des Projektes ${ }^{106} ;$ mgr G. Rostkowski poświęcił swój komunikat zagadnieniu: Byzantine princesses in Rus' from 988 to the haft of the 12th century ${ }^{107}$; prof. M. Salamon przedstawił komunikat: A project of Church Union in 1396-1397: the Polish and Byzantine perspectives ${ }^{108}$; wreszcie prof. T. Wasilewski podjął temat: Inégalité des rangs et des titres entre les ducs et les katépanô, gouverneurs des grandes circonscriptions dans les années 960-1081109. Ponadto wspomniana wyżej dr E. Balicka-Witakowska wygłosiła komunikat nt. Armenian scroll in the Uppsala University Library ${ }^{110}$. Krótkie sprawozdanie z tego wydarzenie przedstawił w Lublinie 25 X 2001 r., na posiedzeniu Komisji Badań nad Antykiem Chrześcijańskim KUL, dr A.J. Frejlich ${ }^{111}$.

${ }^{101}$ Autor niniejszego artykułu pragnie w tym miejscu bardzo serdecznie podziękować dr A.J. Frejlichowi za udostępnienie akt tego kongresu.

${ }^{102}$ Por. XXe Congrès International des Études Byzantines (Collège de France - Sorbonne, 19-25 août 2001), Pré-Actes, II: Tables rondes, Paris 2001, 319.

${ }^{103}$ Por. XX Congrès International des Études Byzantines (Collège de France - Sorbonne, 19-25 août 2001), Pré-Actes, III: Communications libres, s. 103.

104 Por. tamże, s. 393.

${ }^{105}$ Por. tamże, s. 453.

${ }^{106}$ Por. tamże, s. 173.

${ }^{107}$ Por. tamże, s. 195.

${ }^{108}$ Por. tamże, s. 140.

${ }^{109}$ Por. tamże, s. 242.

${ }^{110}$ Por. tamże, s. 36-37.

${ }^{111}$ Por. A.Z. Zmorzanka - J. Figiel, Posiedzenia Komisji Badań nad Antykiem Chrześcijańskim KUL w roku akademickim 2001/2002, VoxP 21 (2001) t. 40-41, 695-696. W tekście tym znalazły 
*

Wreszcie na przedostatnim XXI kongresie bizantynistów w Londynie (2126 VIII 2006) ${ }^{112}$ Polskę reprezentowali: 1) prof. UKSW dr hab. W. Deluga (UKSW), 2) dr A.J. Frejlich (KUL) ${ }^{113}, 3$ ) dr Piotr Ł. Grotowski (UPJPII w Krakowie), 4) dr M.P. Kruk (Muzeum Narodowe w Krakowie i UG), 5) dr Przemysław Marciniak (UŚ) oraz 6) dr Marcin Wołoszyn (URz). W kongresie londyńskim brali również udział Polacy, pracujący na co dzień poza granicami kraju: dr Maja Kominko, absolwentka UJ, reprezentowała Uniwersytet Oksfordzki, dr Andrzej Piotrowski, absolwent Politechniki Warszawskiej, był w Londynie przedstawicielem Uniwersytetu Minnesota (USA), a dr Ewa Zakrzewska wchodziła w skład ekipy holenderskiej, jako reprezentantka Uniwersytetu Amsterdamskiego.

Wszyscy oficjalni przedstawiciele Polski, czyli w/w sześć osób, wygłosili w Londynie komunikaty: prof. W. Deluga poświęcił go zagadnieniu: The miraculous icon of the Virgin from Chetm ${ }^{114}$; dr A.J. Frejlich mówił na temat: From the living icon to the icon of living. Monks and icons in early Byzantium $^{115}$; dr P... Grotowski wygłosił z kolei prelekcję na temat: Military attire of warrior saints - between iconography and written sources ${ }^{116}$; dr M.P. Kruk poświęcił swój komunikat problemowi: The cult of Muscovite icons in the Roman-Catholic churches in the Old Polish Commonwealth (translated by Iwona Zych) ${ }^{117}$. Z kolei dr P. Marciniak zgłosił wystapienie pt. , Stichoi eis ton Adam ” by Ignatios the Deacon and drama in Byzantium ${ }^{118}$; wreszcie dr M. Wołoszyn mówił na temat: The Cross goes East: processes of conversion in central and eastern Europe (1000-1300) in the light of new archaeological finds ${ }^{119}$.

Ponadto wspomniani wyżej Polacy, reprezentujący zagraniczne ośrodki naukowe, przedstawili następujące komunikaty: dr Maja Kominko - Angels

się m.in. następujące zdania (s. 695): „[...] W [Paryżu] gościło [...] ok. 1000 osób z różnych krajów świata. [...]. Spośród polskich naukowców referaty wygłosili M. Salamon (UJ), M. Dąbrowska (UŁ), M. Łaptaś (UKSW), M. Kruk (Muzeum Narodowe w Krakowie) i J. Frejlich (KUL), podejmując zagadnienia recepcji prądów bizantyńskich oraz tendencji unijnych w Polsce".

${ }^{112}$ Serdecznie podziękowanie za udostępnienie niżej podpisanemu akt tego kongresu należy się dr A.J. Frejlichowi.

${ }^{113}$ Nazwisko dr A.J. Frejlicha nie figuruje w aktach kongresowych. Jednak, jak on sam wyjaśnia, stało się to skutkiem niedopatrzenia, ponieważ de facto zgłosił on swój udział w kongresie i jako jedyny przedstawiciel KUL brał czynny udział w jego obradach, wygłaszając komunikat (por. przyp. 116).

114 Por. Proceedings of the 21st International Congress of Byzantine Studies (London, 21-26 August 2006), vol. III: Abstracts of communications, ed. by E. Jeffreys, with the assistance of J. Gilliland, Aldershot 2006, 273-274.

${ }^{115}$ Tytułu tego komunikatu nie ma w aktach kongresowych (por. przyp. 114). Wiadomość ta pochodzi bezpośrednio od dr. A.J. Frejlicha.

${ }^{116}$ Por. Proceedings of the 21st International Congress of Byzantine Studies, vol. III, s. 283-285.

${ }^{117}$ Por. tamże, s. 291-292.

${ }^{118}$ Por. tamże, s. 146-147.

${ }^{119}$ Por. tamże, s. 64-65. 
and stars: astronomy in the Christian Topography ${ }^{120}$, dr Andrzej PiotrowskiRepresentational function of daylight in the Katholikon of Hosios Loukas ${ }^{121}, \mathrm{dr}$ Ewa Zakrzewska - Narrative techniques in Coptic-Bohairic Martyrs Acts ${ }^{122}$. Sprawozdanie z tego kongresu wygłosił 15 III 2007 na posiedzeniu Komisji Badań nad Antykiem Chrześcijańskim KUL dr A.J. Frejlich, a streszczenie jego wystapienia zostało opublikowane w „Vox Patrum”"123.

\section{PODSUMOWANIE}

W okresie międzywojennym odbyło się pięć kongresów bizantynologicznych. Było na nich reprezentowanych w sumie 6 polskich instytucji naukowych: Uniwersytet Jagielloński (UJ), Uniwersytet Jana Kazimierza (UJK) we Lwowie, Uniwersytet Poznański (UP), Uniwersytet Warszawski (UW) oraz Towarzystwo Naukowe im. Tarasa Szewczenki (Lwów) i Ukraińskie Muzeum Narodowe we Lwowie.

Formalnie wzięło w nich udział 16 polskich pracowników naukowych. Byli to (w porządku alfabetycznym): 1) C. Filipowicz-Osieczkowska - UJ (V. Rzym 1936: 2 referaty); 2) O. Halecki - UW (V. Rzym 1936: 1 referat); 3) W. Klinger - UP (III. Ateny 1930: 1 referat); 4) W. Molè - UJ (II. Belgrad 1927: 1 referat; IV. Sofia 1934: 1 referat); 5) L. Piotrowicz - UJ (II. Belgrad 1927: bez referatu); 6) T. Popiel - Towarzystwo Naukowe im. T. Szewczenki/ Lwów (II. Belgrad 1927: nieobecny); 7) J. Sajdak - UP (I. Bukareszt 1924: bez referatu; II. Belgrad 1927: 1 referat; III. Ateny 1930: 3 referaty; V. Rzym 1936: bez referatu); 8) W. Sas-Zaloziecki - UJK (V. Rzym 1936: 2 referaty); 9) L. Sternbach - UJ (II. Belgrad 1927: nieobecny); 10) J. I. Skruteń - Towarzystwo Naukowe im. T. Szewczenki/Lwów (IV. Sofia 1934: nieobecny; V. Rzym 1936: bez referatu); 11) C. Studziński - UJK (II. Belgrad 1927: nieobecny); 12) H. Święcicki - Towarzystwo Naukowe im. T. Szewczenki/Lwów (II. Belgrad 1927: nieobecny) i Ukrańskie Muzeum Narodowe we Lwowie (IV. Sofia 1934: 1 referat; V. Rzym 1936: 1 referat); 13) M. Terecki - Towarzystwo Naukowe im. T. Szewczenki/Lwów (II. Belgrad 1927: nieobecny); 14) A. Turyn - UW (III. Ateny 1930: bez referatu; IV. Sofia 1934: 1 referat); 15) K. Zakrzewski - UJK (II. Belgrad 1927: bez referatu; V. Rzym 1936: bez referatu); 16) T. Zieliński - UW (V. Rzym 1936: 1 referat).

Spośród owych szesnastu osób cztery nie były de facto obecne na żadnym

${ }^{120}$ Por. tamże, s. 118-119.

${ }^{121}$ Por. Proceedings of the 21st International Congress of Byzantine Studies (London, 21-26 August 2006), vol. II: Abstracts of panel papers, ed. by E. Jeffreys, with the assistance of J. Gilliland, Aldershot 2006, 236-237.

${ }^{122}$ Por. Proceedings of the 21st International Congress of Byzantine Studies, vol. III, s. 181-182.

${ }_{123}$ Por. A.Z. Zmorzanka, Posiedzenia Komisji Badań nad Antykiem Chrześcijańskim KUL w roku akademickim 2006/2007, VoxP 27 (2007) t. 50-51, s. 842-843. W tekście tym na s. 842 znajduje się teza, że kongres ten „zgromadził ponad 1000 osób z różnych krajów”. 
kongresie, a figurują jedynie na liście zgłoszonych uczestników; są to: T. Popiel, L. Sternbach, C. Studziński i M. Terecki. Wszystkie te osoby należały do ekipy, która miała reprezentować polską bizantynistykę na kongresie w Belgradzie, w 1927 roku.

Formalnie najwięcej reprezentantów miały UJ - 4 (C. Filipowicz-Osieczkowska, W. Molè, L. Piotrowicz, L. Sternbach/nieobecny) i Towarzystwo Naukowe im. T. Szewczenki/Lwów - 4 (T. Popiel/nieobecny, J.I. Skruteń, H. Święcicki/nieobecny, M. Terecki/nieobecny). Trzy osoby reprezentowały UJK (W. Sas-Zaloziecki, C. Studziński/nieobecny, K. Zakrzewski) i UW (O. Halecki, A. Turyn, T. Zieliński). Uniwersytet Poznański był reprezentowany przez dwie osoby (W. Klinger, J. Sajdak). Natomiast 1 osoba (H. Święcicki) była przedstawicielem Ukrańskiego Muzeum Narodowego we Lwowie. W sumie Polacy wygłosili w okresie międzywojennym na pięciu kongresach bizantynistycznych 16 prelekcji: 11 po niemiecku, 4 po francusku i 1 po włosku.

Najaktywniej uczestniczył w przedmiotowych kongresach prof. J. Sajdak. Wziął on bowiem udział w czterech spotkaniach (I. Bukareszt 1924; II. Belgrad 1927; III. Ateny 1930; V. Rzym 1936). Po dwa kongresy „zaliczyli” natomiast de facto: W. Molè (II. Belgrad 1927; IV. Sofia 1934); H. Święcic$\mathrm{ki}^{124}$ (IV. Sofia 1934; V. Rzym 1936) oraz K. Zakrzewski (II. Belgrad 1927; V. Rzym 1936).

W okresie powojennym przedstawiciele Polski (bez wliczania polskich badaczy pracujących poza krajem) uczestniczyli do roku 2006 w 11-stu kongresach bizantynistycznych, poczynając od roku 1958 (Monachium). Reprezentowali oni 10 uniwersytetów (KUL, UAM, UG, UJ, UKSW, UŁ, UPJPII (Kraków), URz, UŚ, UW) oraz: Muzeum Budownictwa Ludowego w Sanoku, Muzeum Narodowe w Krakowie, Muzeum Narodowe w Warszawie i PAN (Warszawa).

Formalnie w kongresach tych wzięło udział w sumie 28 pracowników naukowych z Polski. Byli to (w porządku alfabetycznym): 1) A. Biernacki - UAM (XVIII. Moskwa 1991: 1 komunikat); 2) W. Ceran - UŁ (XV. Ateny 1976: bez referatu; XVI. Wiedeń 1981: bez referatu); 3) H. Cichocka UW (XVI. Wiedeń 1981: 1 komunikat; XVIII. Moskwa 1991: bez referatu); 4) M. Dąbrowska - UŁ (XVIII. Moskwa 1991: 1 komunikat; XIX. Kopenhaga 1996: 1 komunikat; XX. Paryż 2001: 1 komunikat); 5) W. Deluga - Muzeum Narodowe w Warszawie (XVIII. Moskwa 1991: 1 komunikat) i UKSW (XXI. Londyn 2006: 1 komunikat); 6) H. Evert-Kappesowa - UŁ (XII. Ochryda

${ }^{124}$ H. Święcicki zgłosił również swój udział w II Kongresie Bizantynologicznym w Belgradzie (1927), lecz ostatecznie nie przybył do stolicy Serbii, gdzie miał reprezentować lwowskie Towarzystwo Naukowe im. T. Szewczenki, por. Deuxième Congrès International des Études Byzantines (Belgrad 1927), 200-201 i 206. Natomiast w Sofii (1934) i w Rzymie (1936) badacz ten występował jako przedstawiciel Ukraińskiego Muzeum Narodowego we Lwowie. 
1961: 1 referat; XIII. Oksford 1966: 1 referat; XV. Ateny 1976: bez referatu); 7) A.J. Frejlich - KUL (XX. Paryż 2001: 1 komunikat; XXI. Londyn 2006: 1 komunikat); 8) W. Godlewski - UW (XVI. Wiedeń 1981: 1 komunikat); 9) P.Ł. Grotowski - UPJPII Kraków (XXI. Londyn 2006: 1 komunikat); 10) B. Hirszenberg - Muzeum Budownictwa Ludowego w Sanoku (XIII. Oksford 1966: 1 komunikat ${ }^{125}$ ) i miejsce pracy nieznane ${ }^{126}$ (XIV. Bukareszt 1971: bez referatu; XV. Ateny 1976: 1 komunikat ${ }^{127}$ ); 11) O. Jurewicz - UW (XIV. Bukareszt 1971: bez referatu; XVI. Wiedeń 1981: bez referatu); 12) J. Kłosińska - Muzeum Narodowe w Krakowie (XIV. Bukareszt 1971: bez referatu); 13) M.P. Kruk - Muzeum Narodowe w Krakowie (XX. Paryż 2001: 1 komunikat) oraz Muzeum Narodowe w Krakowie i UG ${ }^{128}$ (XXI. Londyn 2006: 1 komunikat); 14) K. F. Kumaniecki - UW (XI. Monachium 1958: bez referatu); 15) M. Łaptaś - UKSW (XX. Paryż 2001: 1 komunikat); 16) A.T. Łukaszewicz - UW (XVII. Waszyngton 1986: 1 komunikat); 17) I. Malinowska-Kwiatkowska - UJ (XV. Ateny 1976: 1 komunikat; XVI. Wiedeń 1981: 1 komunikat); 18) P. Marciniak - UŚ (XXI. Londyn 2006: 1 komunikat); 19) W. Molè - UJ (XII. Ochryda 1961: 1 komunikat); 20) A. Poppe - UW (XV. Ateny 1976: bez referatu; XVI. Wiedeń 1981: bez referatu; XVII. Waszyngton 1986: 1 komunikat; XVIII. Moskwa 1991: bez referatu); 21) J. Prostko-Prostyński - UAM (XX. Paryż 2001: 1 komunikat); 22) G. Rostkowski PAN Warszawa (XX. Paryż 2001: 1 komunikat); 23) A. Różycka-Bryzek - UJ (XIV. Bukareszcie 1971: bez referatu; XVI. Wiedeń 1981: 1 komunikat); 24) J. Sajdak (?) - UAM (XI. Monachium 1958: bez referatu) ${ }^{129}$; 25) M. Salamon - UJ (XVIII. Moskwa 1991: 1 komunkat; XIX. Kopenhaga 1996: 1 komunikat; XX. Paryż 2001: 1 komunikat); 26) T. Ulewicz - UJ (XVIII. Moskwa 1991: 1 komunikat); 27) T. Wasilewski - UW (XII. Ochryda 1961: 1 komunikat; XIV. Bukareszt 1971: 1 komunikat; XV. Ateny 1976: 1 komunikat; XVI. Wiedeń: 1 komunikat; XVII. Waszyngton 1986: 1 komunikat; XVIII. Moskwa 1991: 1 referat i 1 komunikat; XX. Paryż 2001: 1 komunikat); 28) M. Wołoszyn - URz (XXI. Londyn 2006: 1 komunikat).

Najwięcej pracowników naukowych reprezentowało UW - 7 (H. Cichocka, W. Godlewski, O. Jurewicz, K. F. Kumaniecki, A. T. Łukaszewicz, A. Poppe, T. Wasilewski). Następne w kolejności są: UJ - 5 (I. Malinowska-

${ }^{125}$ Dane dotyczące pobytu B. Hirszenberg w Oksfordzie pochodzą z jej własnego sprawozdania na ten temat, por. przyp. 58 .

${ }^{126}$ Por. przyp. 57. Nie udało się natomiast ustalić, gdzie B. Hirszenberg pracowała w roku 1971 i 1976

${ }^{127}$ Por. przyp. 61 i 66-67.

${ }^{128}$ Por. Proceedings of the 21st International Congress of Byzantine Studies, vol. III, s. 291. Na tej stronie jest następujący wpis: „Mirosław Kruk. University of Gdansk and National Museum in Cracow, Poland".

${ }^{129} \mathrm{~W}$ aktach kongresowych brak nazwiska profesora. Hipoteza o jego udziale w tym kongresie ma swe źródło w biografii tego badacza, por. przyp. 9. 
-Kwiatkowska, W. Molè, A. Różycka-Bryzek, M. Salamon, T. Ulewicz) i UŁ - 3 (W. Ceran, M. Dąbrowska, H. Evert-Kappesowa). Mniej licznie były reprezentowane inne ośrodki: UAM - 3(?) (A. Biernacki, J. Prostko-Prostyński, J. Sajdak (?) - por. przyp. 9 i 130); UKSW - 2 (W. Deluga, M. Łaptaś); KUL - 1 (A. Frejlich); UG - 1 (M. P. Kruk) - por. przyp. 129; UPJPII (Kraków) 1 (P. Ł. Grotowski); URz - 1 (M. Wołoszyn); UŚ - 1 (P. Marciniak). Reprezentacja innych instytucji naukowo-badawczych przedstawiała się następująco: Muzeum Budownictwa Ludowego w Sanoku - 1 (B. Hirszenberg); Muzeum Narodowe w Krakowie - 2 (J. Kłosińska, M. P. Kruk); Muzeum Narodowe w Warszawie - 1 (W. Deluga); PAN (Warszawa) - 1 (G. Rostkowski). Polacy wygłosili łącznie 41 prelekcji130: 19 po angielsku, $17 \mathrm{w}$ języku francuskim, 2 po niemiecku i $2 \mathrm{w}$ języku rosyjskim ${ }^{131}$.

W powojennych kongresach najczęściej uczestniczył prof. T. Wasilewski - 7. Drugi pod tym względem był prof. A. Poppe - 4. Trzykrotnie brali udział w omawianych kongresach: M. Dąbrowska, H. Evert-Kappesowa, B. Hirszenberg i M. Salamon. Dwukrotnymi uczestnikami tych spotkań byli: W. Ceran, H. Cichocka, W. Deluga, A. Frejlich, O. Jurewicz, M. Kruk, I. Malinowska-Kwiatkowska i A. Różycka-Bryzek.

Podobnie jak w przypadku kongresów przedwojennych, również i tutaj występują znaczne rozbieżności odnośnie liczby uczestników poszczególnych spotkań pomiędzy danymi przytoczonymi przez M. Nystazopoulou-Pélékidou (Tabela II), które mogą uchodzić dziś za swego rodzaju standardowe ujęcie statystyczne odbytych dotąd kongresów, a szacunkami V. Tăpkovej-Zaimovej oraz danymi zawartymi w polskich sprawozdaniach postkongresowych. W przypadku IX kongresu w Salonikach ta ostatnia stwierdza: „En effet, il y a eu environ 400 adhérents dont 300 participants effectifs" 132 , podczas gdy M. Nystazopoulou-Pélékidou podaje liczbę 414 uczestników.

Podobnie ma się rzecz, jeśli chodzi o XI spotkanie bizantynistów w Monachium. W kontekście tego kongresu V. Tăpkova-Zaimova pisze „Mon information principale sur le $\mathrm{XI}^{\mathrm{e}}$ Congrès (15-17.IX.1958, Munich) vient de

${ }^{130} \mathrm{~W}$ powyższej statystyce ogólnej jest mowa o 41 referatach, lecz sumując statystykę językową otrzymuje się liczbę 40 prelekcji. Różnica ta pochodzi stąd, że nie udało się ustalić, w jakim języku wygłosiła swój komunikat w Oksfordzie (1966) B. Hiszenberg (por. przyp. 58). Ponadto przyjęto, że rzeczona B. Hirszenberg wygłosiła w Atenach (1976) tylko jeden komunikat w języku francuskim, a jedynie sam tytuł tego wystapienia z nieznanych powodów został podany w aktach kongresowych również po angielsku (por. przyp. 66-67).

${ }^{131}$ Proporcje językowe uległy niemal rewolucyjnej zmianie na XXII Międzynarodowym Kongresie Bizantynistów w Sofii w roku 2011, gdzie na 35 zgłoszonych oficjalnie prelekcji Polaków 28 miało być wygłoszonych po angielsku, 3 po francusku, 2 w języku niemieckim i 2 po rosyjsku, por. P. Kochanek, XXII Międzynarodowy Kongres Bizantynistów (Sofia, 22-27 VIII 2011), VoxP 31 (2011) t. 56, 942-951.

${ }^{132}$ Por. Tăpkova-Zaimova, Entre deux congrès, s. 48. 
M. Dimităr Angelov qui, à son retour du Congrès, a publié un compte rendu intéressant sur la présence de 450 participants, venus de 36 pays et les problèmes abordés"133. Tymczasem przedmiotowa tabela greckiej badaczki mówi o 353 „kongresmenach”. Tak duża rozbieżność pomiędzy danych jest prawdopodobnie efektem przypadkowego błędu, czy też przeoczenia którejś z nich.

Co do XII-go kongresu w Ochrydzie badaczka bułgarska stwierdza: „il y avait 500 participants de 29 pays" ${ }^{134}$, podczas gdy M. Nystazopoulou-Pélékidou określa liczbę uczestników na 400 osób.

Liczbę badaczy partycypujących w kongresie oksfordzkim (XIII) obie uczone pomijają milczeniem. Jednak B. Hirszenberg pisze, że był to kongres, „W którym brało udział 600 osób z całego świata” (por. przyp. 58).

Ciekawie pod tym względem przedstawia się XIV kongres odbyty w Bukareszcie. Analiza listy jego oficjalnych uczestników, przeprowadzona przez niżej podpisanego, mówi o 568 osobach (por. przyp. 61), podczas gdy tabela M. Nystazopoulou-Pélékidou podaje liczbę 564 uczestników i z tym zgadza się również badaczka bułgarska, choć jednocześnie podaje inną liczbę krajów pochodzenia tych osób ${ }^{135}$. Te minimalne rozbieżności mieszczą się jednak $\mathrm{w}$ granicach prostego przeoczenia.

Duże rozbieżności pomiędzy obu badaczkami powracają w przypadku XV kongresu w Atenach. V. Tăpkova-Zaimova stwierdza bowiem, że ,il y a eu une participation considérable de plus de 600 délégués, venus de 30 pays"136, natomiast badaczka grecka podaje w swej tabeli, że do Aten przybyło 874 bizantynistów.

Podobnie ma się rzecz z XVI kongresem w Wiedniu. M. Nystazopoulou-Pélékidou mówi o 751 uczestnikach z 35 krajów. Bułgarska uczona koryguje tutaj znacznie dane swej greckiej koleżanki pisząc, że ,il y a eu la participation d'environ 900 byzantinistes de 34 pays" ${ }^{137}$. Tymczasem uczestniczący w tymże kongresie prof. W. Ceran napisał w swym sprawozdaniu rzecz następującą: „W Kongresie wzięło udział 843 bizantynistów (wedle danych sekretariatu). [...]. Wygłoszono ogółem 33 referaty i 337 komunikatów” (por. przyp. 72). Natomiast prof. H. Cichocka, która także brała udział w rzeczonym kongresie, stwierdziła w sprawozdaniu, że „w kongresie wzięło udział około 1000 bizantynistów" (por. przyp. 72).

Mniej kontrowersji co do liczby uczestników nastręcza XVII kongres, który obradował w Waszyngtonie. M. Nystazopoulou-Pélékidou pisze w tym przypadku o 413 bizantynistach z 30-stu krajów, natomiast V. Tăpkova-Zaimova zanotowała krótko, iż ,il y avait 500 participants de 30 pays"138.

\footnotetext{
${ }^{133}$ Por. tamże, s. 49.

134 Por. tamże.

135 Por. tamże, s. 51: „564 délégués de 35 pays”.

136 Por. tamże, s. 53.

137 Por. tamże, s. 54.

${ }^{138}$ Por. tamże, s. 55.
} 
Znaczne różnice szacunków powracają w kontekście kongresu moskiewskiego (XVIII). Tabela greckiej badaczki określa liczbę uczestników na 1300, podczas gdy zdaniem Bułgarki „en plus des 300 participants soviétiques il y a eu 450 représentants de 38 autres pays"139. Natomiast autorzy polskiego sprawozdania z tegoż spotkania bizantynistów piszą, że kongres ,zgromadził około 1500 uczestników" (por. przyp. 92).

XIX kongres w Kopenhadze V. Tăpkova-Zaimova opatrzyła następującym komentarzem statystycznym: „Il y a eu 350 participants de 33 pays” ${ }^{140}$, gdy tymczasem jej grecka koleżanka pisała o 430 ,kongresmenach”, reprezentujących 34 kraje.

XX kongres w Paryżu miał zgodnie za powyższą Tabelą II zgromadzić 995 uczestników z 33 państw. V. Tăpkova-Zaimova koryguje nieco te liczby pisząc, że „il y avait près de 900 délégués de 36 pays”" ${ }^{141}$. Natomiast w polskim sprawozdaniu z tegoż kongresu jest mowa o „ok. 1000 osób z różnych krajów świata" (por. przyp. 112).

Wreszcie przedostatni XXI kongres mający miejsce w Londynie, którego liczbę uczestników określa rzeczona tabela na 948 (40 krajów), prof. V. Tăpkova-Zaimova ujmuje w ramy takiej oto statystyki: „Quarente pays s’y étaient annoncés avec un millier de participants, mais en réalité, 750 exposés ont été entendus" ${ }^{142}$. KUL-owski sprawozdawca zaś napisał krótko, iż kongres ,zgromadził ponad 1000 osób z różnych krajów" (por. przyp. 124).

Powyższe analizy wykazują pewną niekiedy daleko idącą nieprecyzyjność postkongresowych danych statystycznych, przytaczanych w różnych sprawozdaniach. Liczby te są często zaokrąglane, z tendencją do ich zawyżania. Przytoczone tutaj rozbieżności statystyczne wydają się być dobrą ilustracją tego problemu. Warto o tym pamiętać przy lekturze statystyk w sprawozdaniach kongresowych. $Z$ drugiej zaś strony zestawienia te dają pewien całościowy obraz arytmetycznego aspektu odbytych dotąd kongresów bizantynistycznych. W tym sensie spełniają one w miarę przyzwoicie swoje zadanie pod warunkiem, że pamięta się stale o potencjalnych mankamentach tego typu danych.

Przedstawione wyżej oficjalne dane statystyczne, odnoszące się do udziału Polaków w 21 kongresach bizantynistycznych w latach 1924-2006, stanowią wyraźny kontrast $\mathrm{z}$ danymi odnoszącymi się do XXII Międzynarodowego Kongresu Bizantynistów (Sofia, 22-27 VIII 2011), gdzie uczestniczyło oficjalnie aż 38 Polaków (34 badaczy z kraju oraz 4 osoby, które swe studia magisterskie ukończyły w Polsce, a obecnie są związane z konkretnymi ośrod-

\footnotetext{
${ }^{139}$ Por. tamże, s. 58

${ }^{140}$ Por. tamże, s. 60

${ }^{141}$ Por. tamże, s. 62.

${ }^{142}$ Por. tamże, s. 63.
} 
kami zagranicznymi), którzy wygłosili w sumie 35 prelekcji ${ }^{143}$. Liczba ta niewiele odbiega od liczby 41 wystapień polskich badaczy na wszystkich wcześniejszych kongresach, zorganizowanych po II wojnie światowej (por. przyp. 131-132). Ten skokowy wzrost aktywnego uczestnictwa polskich badaczy w przedmiotowych kongresach ilustruje do pewnego stopnia ogrom zmian, jaki dokonał się w nauce polskiej w ostatnim okresie. Niewatpliwie polska bizantynistyka wychodzi z okresu PRL-owskiej zapaści i ujawnia swój wielki potencjał, tkwiący w młodym pokoleniu badaczy. Jest to również efekt pracy tych niewielu bizantynistów poprzedniego pokolenia, którzy w okresie niesprzyjającym rozwojowi tej dyscypliny, starali się mimo wszystko kształcić przyszłe kadry, czego najlepszym przykładem jest środowisko łódzkie ze śp. prof. W. Ceranem na czele.

\section{THE PARTICIPATION OF POLES IN 21 INTERNATIONAL CONGRESSES OF BYZANTINE STUDIES IN THE YEARS 1924-2006}

\section{(Summary)}

This article presents the share of Polish researchers in the field of Byzantine history in 21 of the International Congresses of Byzantine Studies, held in the years 1924-2006. The starting point of this article are the official statistics of these conferences, developed by prof. M. Nystazopoulou-Pélékidou and prof. V. Tăpkova-Zaimova. These official statistics have been revised and expanded with the participation of Poles in these congresses. Consequently, given not only the number of Poles taking part in various congresses, but also the titles given by their papers, the language in which these papers were delivered and scientific centers, what these researchers represented. Consideration was also given Polish researchers working abroad. In this way was constructed some kind of synthesis, which shows from a statistical point of view, the contribution of Polish investigators of Byzantine history at different congresses, held in the years 1924-2006.

${ }^{143}$ Por. Kochanek, XXII Międzynarodowy Kongres Bizantynistów, s. 950. 
